PNNL-19562

U.S. DEPARTMENT OF ENERGY

Prepared for the U.S. Department of Energy under Contract DE-AC05-76RL01830

\title{
Assessment of the 3410 Building Filtered Exhaust Stack Sampling Probe Location
}

\author{
JA Glissmeyer \\ JE Flaherty
}

July 2010

\section{Pacific Northwest}

NATIONAL LABORATORY

Proudly Operated by Battelle Since 1965 


\title{
DISCLAIMER
}

This report was prepared as an account of work sponsored by an agency of the United States Government. Neither the United States Government nor any agency thereof, nor Battelle Memorial Institute, nor any of their employees, makes any warranty, express or implied, or assumes any legal liability or responsibility for the accuracy, completeness, or usefulness of any information, apparatus, product, or process disclosed, or represents that its use would not infringe privately owned rights. Reference herein to any specific commercial product, process, or service by trade name, trademark, manufacturer, or otherwise does not necessarily constitute or imply its endorsement, recommendation, or favoring by the United States Government or any agency thereof, or Battelle Memorial Institute. The views and opinions of authors expressed herein do not necessarily state or reflect those of the United States Government or any agency thereof.

\author{
PACIFIC NORTHWEST NATIONAL LABORATORY \\ operated by \\ BATTELLE \\ for the \\ UNITED STATES DEPARTMENT OF ENERGY \\ under Contract DE-ACO5-76RL01830
}

Printed in the United States of America
Available to DOE and DOE contractors from the Office of Scientific and Technical Information,
P.O. Box 62, Oak Ridge, TN 37831-0062;
ph: (865) 576-8401
fax: (865) 5765728
email: reports@adonis.osti.gov

\author{
Available to the public from the National Technical Information Service, \\ U.S. Department of Commerce, 5285 Port Royal Rd., Springfield, VA 22161 \\ ph: (800) 553-6847 \\ fax: (703) 605-6900 \\ email: orders@nits.fedworld.gov \\ online ordering: http://www.ntis.gov/ordering.htm
}


PNNL-19562

RPT-STMON-005

\title{
Assessment of the 3410 Building Filtered Exhaust Stack Sampling Probe Location
}

\author{
J. A. Glissmeyer \\ J. E. Flaherty
}

July 2010

Prepared for the U.S. Department of Energy

under Contract DE-AC05-76FL01830

Pacific Northwest National Laboratory

Richland, Washington 99352 
Completeness of Testing

This report describes the results of work and testing specified by test plan TP-STMON001. The work and any associated testing followed the quality assurance requirements outlined in the test specification/plan. The descriptions provided in this test report are an accurate account of both the conduct of the work and the data collected. Test plan results are reported. Also reported are any unusual or anomalous occurrences that are different from expected results. The test results and this report have been reviewed and verified.

Approved:

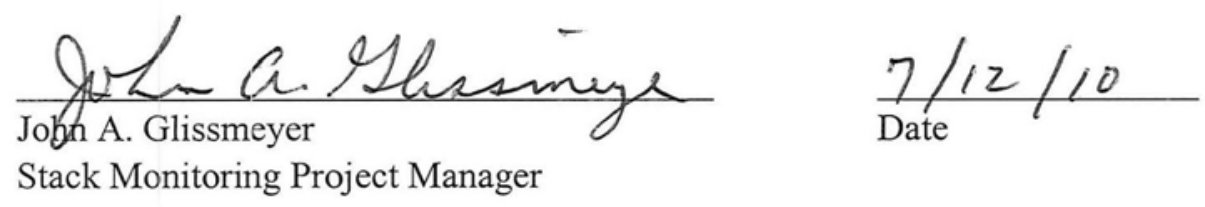




\section{Summary}

Pacific Northwest National Laboratory performed several tests in the exhaust air discharge from the new 3410 Building Filtered Exhaust Stack to determine whether the location of the air sampling probe for emissions monitoring is acceptable. The method followed involved adopting the results of a previously performed test series from a system with a similar configuration, followed by several tests on the actual system to verify the applicability of the previously performed tests. The qualification criteria for these types of stacks include metrics concerning 1) uniformity of air velocity, 2) sufficiently small flow angle with respect to the axis of the duct, 3) uniformity of tracer gas concentration, and 4) uniformity tracer particle concentration.

Section 1 of this report provides background information concerning the tests for the 3410 Building, while Section 2 describes the testing strategy, including the criteria for the applicability of the model results and the test matrix. Section 3 describes the flow angle and velocity uniformity tests conducted at the 3410 Building Filtered Exhaust Stack. Sections 4 and 5 present the test results and conclusions, respectively. Test data sheets and applicable qualification results from previously tested stack models are included in Appendices.

The testing conducted from the similarly designed scale model stack was determined to be applicable to the current design of the 3410 Building Filtered Exhaust Stack. As a result, this new system also meets the qualification criteria given in the ANSI/HPS N13.1-1999 standard. Changes to the system configuration or operations outside the bounds described in this report (e.g., exhaust stack velocity changes, relocation of sampling probe) will require re-testing or re-evaluation to determine compliance. 



\section{Acronyms}

$\begin{array}{ll}\text { acfm } & \text { actual cubic feet per minute } \\ \text { AD } & \text { aerodynamic diameter } \\ \text { ANSI } & \text { American National Standards Institute } \\ \text { ASME } & \text { American Society of Mechanical Engineers } \\ \text { CFR } & \text { Code of Federal Regulations } \\ \text { COV } & \text { coefficient of variation } \\ \text { DIA } & \text { number of duct diameters, distance divided by duct diameter } \\ \text { DOE } & \text { U.S. Department of Energy } \\ \text { DV } & \text { hydraulic diameter and the mean velocity } \\ \text { EPA } & \text { U.S. Environmental Protection Agency } \\ \text { FA } & \text { flow angle test run } \\ \text { HDI } & \text { "How Do I...?" } \\ \text { HPS } & \text { Health Physics Society } \\ \text { M\&TE } & \text { materials and testing equipment } \\ \text { NQA } & \text { National Quality Assurance } \\ \text { PNNL } & \text { Pacific Northwest National Laboratory } \\ \text { PSF } & \text { Physical Sciences Facility } \\ \text { QA } & \text { quality assurance } \\ \text { R\&D } & \text { research and development } \\ \text { scfm } & \text { standard cubic feet per minute } \\ \text { STMON } & \text { velocity uniformity test run } \\ \text { TI } & \text { VT }\end{array}$





\section{Acknowledgments}

This work was supported by Project 48043, a Line-Item-funded project to develop, design, and construct the Physical Sciences Facility. Pacific Northwest National Laboratory (PNNL) is operated for the U.S. Department of Energy by Battelle under Contract DE-ACO5-76RL01830.

Preparing and executing these tests involved a number of PNNL staff members. We would like to particularly acknowledge the support of our quality engineer, Kirsten Meier, and administrative support from Mona Champion and Chrissy Charron. Robert Steele, John Hickman, Dan Edwards, and Matthew Barnett provided technical, logistical, and moral support for these tests. In addition, Carmen Arimescu, Matthew Barnett, and Ernest Antonio provided technical reviews. Wayne Cosby provided editorial support for this report. 



\section{Contents}

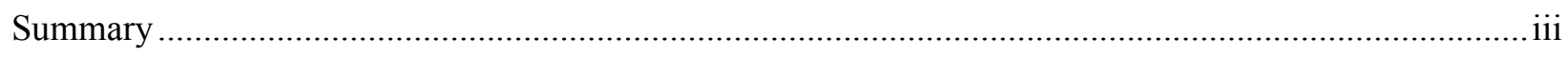

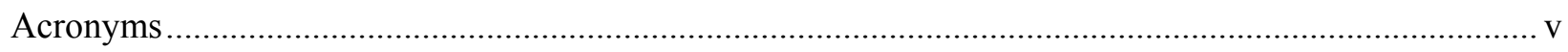

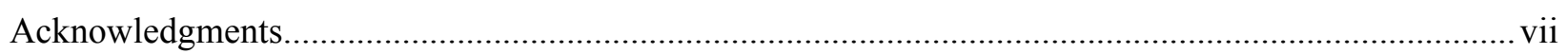

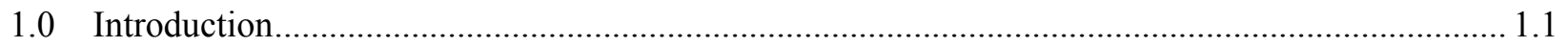

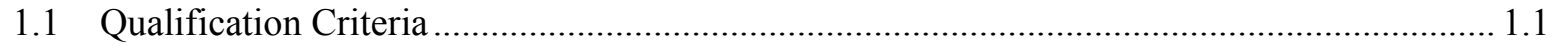

1.2 Building 3410 Filtered Exhaust Stack Configuration ..................................................... 1.2

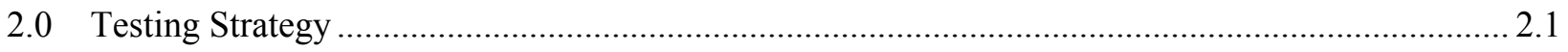

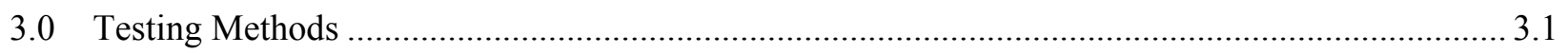

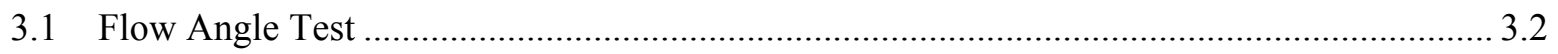

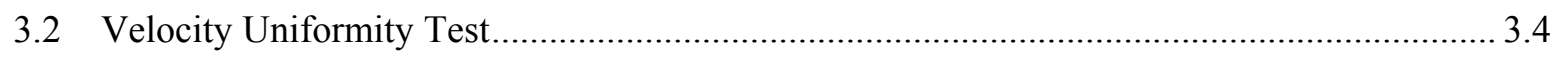

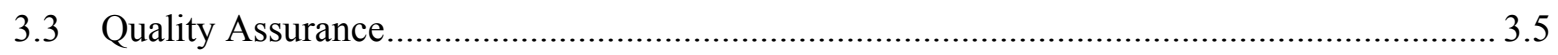

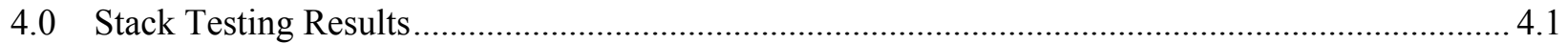

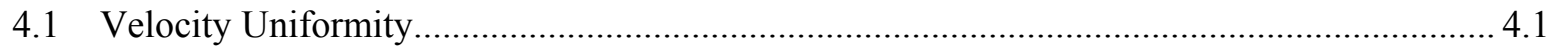

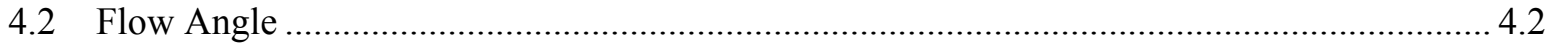

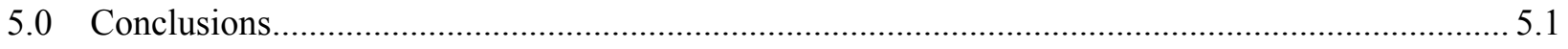

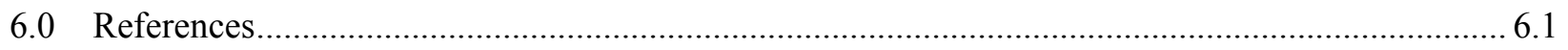

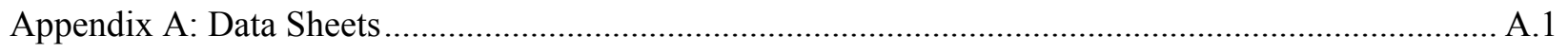

Appendix B: Applicable Qualification Results from Model Stack .........................................................1 


\section{Figures}

1.1. Plan View of the 3410 Building Filtered Exhaust Stack .......................................................... 1.3

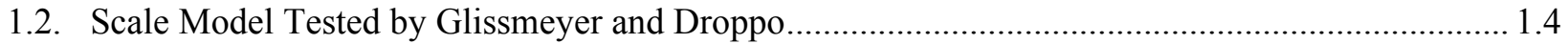

3.1. Layout of Test Ports and Other Duct Features at the 3410 Stack ............................................. 3.1

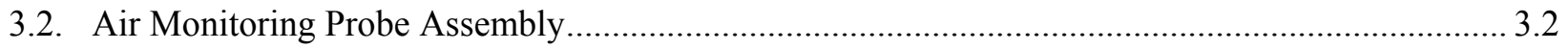

3.3. Flow Angle Indicator and Pitot Tube Installed on 3410 Stack ........................................................ 3.3

3.4. Slant Tube Manometer on 3430 Inspection Hatch Cover.............................................................. 3.4

3.5. Electronic Manometer Connected to Pitot Tube............................................................................... 3.5

\section{Tables}

1.1. Comparison of Model and Actual Stack Dimensions................................................................... 1.4

2.1. List of HV-C2 Velocity Uniformity Test Results with Dampers Installed.................................... 2.1

2.2. Ranges of Acceptable Diameter $\times$ Velocity Values and Reynolds Numbers ................................ 2.2

2.3. Minimum Test Runs for 3410 Building Qualification............................................................... 2.2

4.1. 3410 Duct Depth Measurements............................................................................................. 4.1

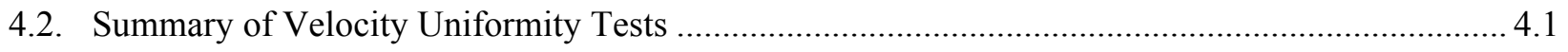

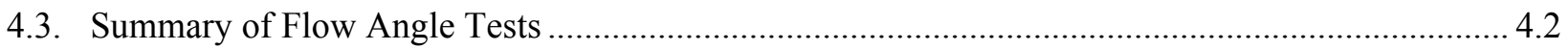




\subsection{Introduction}

The new construction of the Physical Sciences Facility (PSF) at the Pacific Northwest National Laboratory (PNNL) incorporates three laboratory buildings that will house PNNL radiological capabilities. As a result, PNNL has determined that emissions monitoring must be conducted for radionuclides in the exhaust air discharge of these buildings. The air monitoring system is required to conform to applicable federal regulations (Title 40 of the Code of Federal Regulations Part 61 [40 CFR 61], Subpart H), which in turn requires a sampling probe in the exhaust stream to conform to the

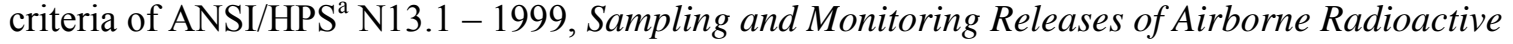
Substances from the Stack and Ducts of Nuclear Facilities. This standard requires that a series of tests be performed to demonstrate the acceptability of the location of the air sampling probe in the system. A facility may choose from one of the three approaches to demonstrate compliance with the federal standards:

1. Perform a full test series on the actual exhaust system

2. Perform the full test series on a scale model of the exhaust system, followed by a partial test of the actual exhaust system to verify the validity of the model results

3. Adopt the results from previously performed full test series for a system with similar configuration, followed by a partial test of the actual exhaust system to verify the applicability of the previous test results.

The third approach was selected to evaluate the acceptability of the location of the air sampling probe in the 3410 Building Filtered Exhaust Stack to monitor discharged air for radionuclides. Consequently, a limited series of tests was performed on the actual exhaust system using the criteria for qualifying the location of a stack monitoring probe and the configuration of the 3410 Building Filtered Exhaust Stack, as described in this report. Also included in this report are the results from the previously performed full test series that serve as the basis for compliance with the standard. Tests on the 3410 Building, also known as the Materials Science and Technology Laboratory, were conducted on May 13 and 14, 2010.

\subsection{Qualification Criteria}

The qualification criteria for a stack air monitoring probe location are taken from ANSI/HPS N13.1-1999 and are paraphrased as follows:

1. Uniform Air Velocity - It is important that the gas velocity across the stack cross-section where the sample is extracted be fairly uniform. Consequently, the velocity is measured at several points in the stack at the position of the sampling nozzle. The uniformity is expressed as the variability of the measurements about the mean. This is expressed using the coefficient of variation $(\mathrm{COV}){ }^{(\mathrm{b})}$ which is the standard deviation divided by the mean and expressed as a percentage - the lower the COV value, the more uniform the velocity. The acceptance criterion is that the COV of the air velocity must be $\leq 20 \%$ across the sampling plane.

(a) The American National Standards Institute delegates the writing, publication and maintenance of this standard to the Health Physics Society, McLean, Virginia.

(b) Coefficient of variation is considered "dated" terminology. The modern terminology is percent relative standard deviation. However, because the standard uses the older terminology, it will likewise be used here. 
2. Angular Flow-Sampling nozzles are typically aligned with the axis of the stack. If the air travels up the stack in cyclonic fashion, the air velocity vector approaching a sampling nozzle could be sufficiently misaligned with the nozzle to impair the extraction of particles. Consequently, the flow angle is measured in the duct at the location of the sampling probe. The average air-velocity angle must not deviate from the axis of the duct by more than $20^{\circ}$.

3. Uniform Concentration of Tracer Gases-A uniform contaminant concentration in the sampling plane enables the extraction of samples that represent the true concentration within the duct. The uniformity of the concentration is first tested using a tracer gas to represent gaseous effluents. The fan is a good mixer, so injecting the tracer downstream of the fan provides worst-case results. The acceptance criteria are that 1 ) the COV of the measured tracer gas concentration is $\leq 20 \%$ across the sampling location, and 2) at no point in the sampling location does the concentration vary from the mean by $>30 \%$.

4. Uniform Concentration of Tracer Particles - The second set of tests addressing contaminant concentration uniformity at the sampling position uses tracer particles large enough to exhibit inertial effects. Tracer particles of $10 \mu \mathrm{m}$ aerodynamic diameter (AD) are used by default unless it is known that larger contaminant particles will be present in the airstream. The acceptance criterion is that the COV of particle concentration is $\leq 20 \%$ across the sampling location.

Glissmeyer and Droppo (2007) conducted tests of a similar stack configuration using a scale model and concluded that the stack was compliant with these criteria. Section 5.2.2.2 of the ANSI/HPS N13.1-1999 standard defines additional criteria for applying the results of the scale model for the actual building stack. A summary of these criteria as applicable for the 3410 Building stack follows:

- The scale model and its sampling location must be geometrically similar to the actual 3410 Building Filtered Exhaust Stack.

- The product of the hydraulic diameter and the mean velocity (DV) of the scale model must be within a factor of six of the DV for the actual 3410 Building Filtered Exhaust Stack.

- The Reynolds number for the model and actual stacks must each be $>10,000$.

The scale-model results are considered valid if the following are shown by testing on the actual stacks:

- The velocity profile in the actual 3410 Building stack meets the uniformity criterion.

- The velocity uniformity (\% COV) values for the model and actual stacks agree to within 5\%.

- The flow angle criterion is met on the actual 3410 Building stack.

\subsection{Building 3410 Filtered Exhaust Stack Configuration}

Figure 1.1 shows a schematic of the plan view of the 3410 Building Filtered Exhaust Stack. Figure 1.2 shows the scale model stack (designated as HV-C2) tested by Glissmeyer and Droppo (2007). The two designs differ in that the model stack (except for the bend upwards at the discharge end) is rotated $90^{\circ}$ around its long axis so that the air from the fans enters the straight section from the side rather than from the bottom. This should have no effect on the uniformity of tracers and the air velocity uniformity and flow angles. The model stack was tested with both one and both fans operating, which 
covers the possible operating modes of the actual stack. Table 1.1 lists key dimensional and flow parameters for both the model stack and the 3410 Building Filtered Exhaust Stack.

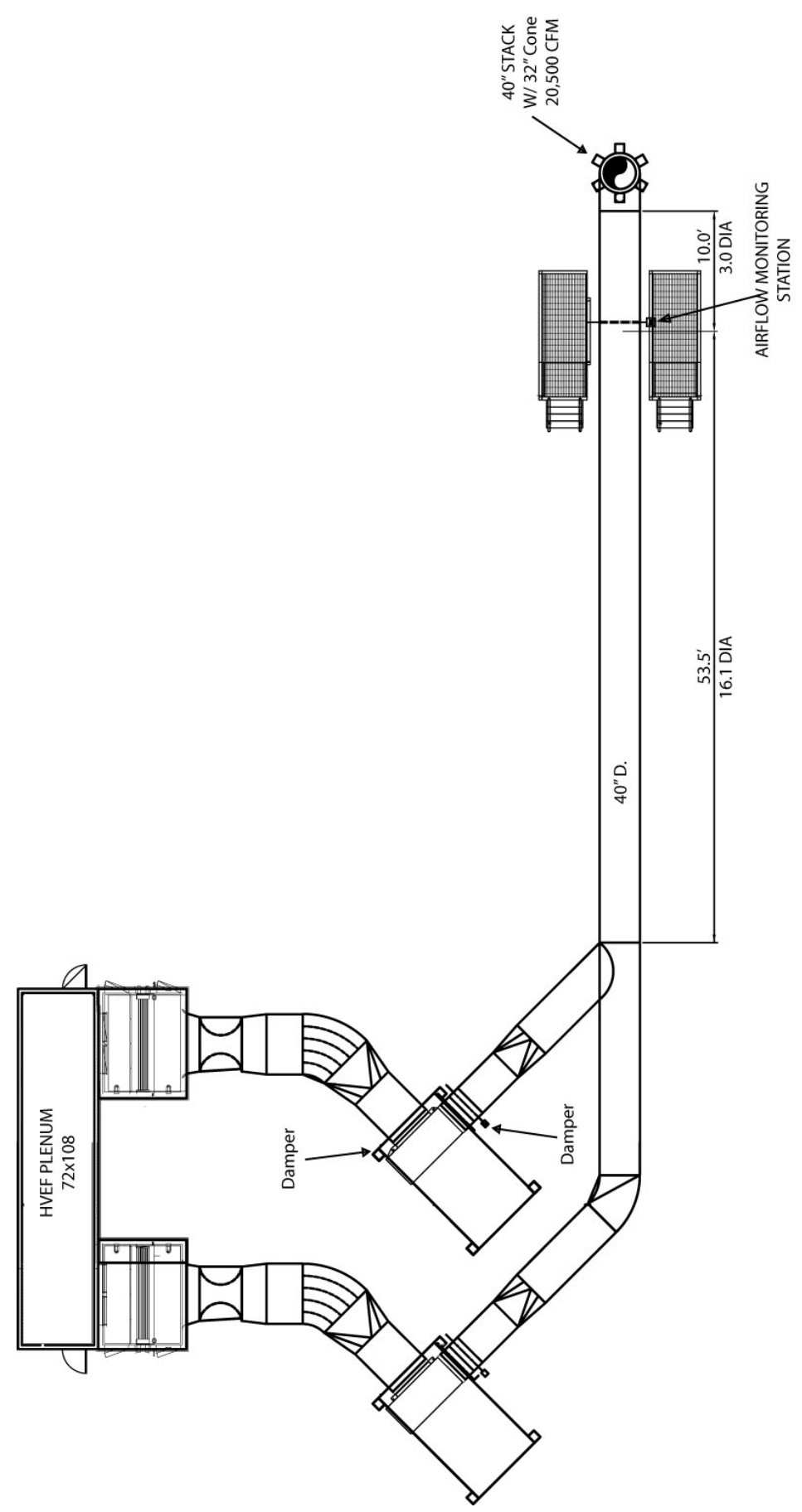

Figure 1.1. Plan View of the 3410 Building Filtered Exhaust Stack 


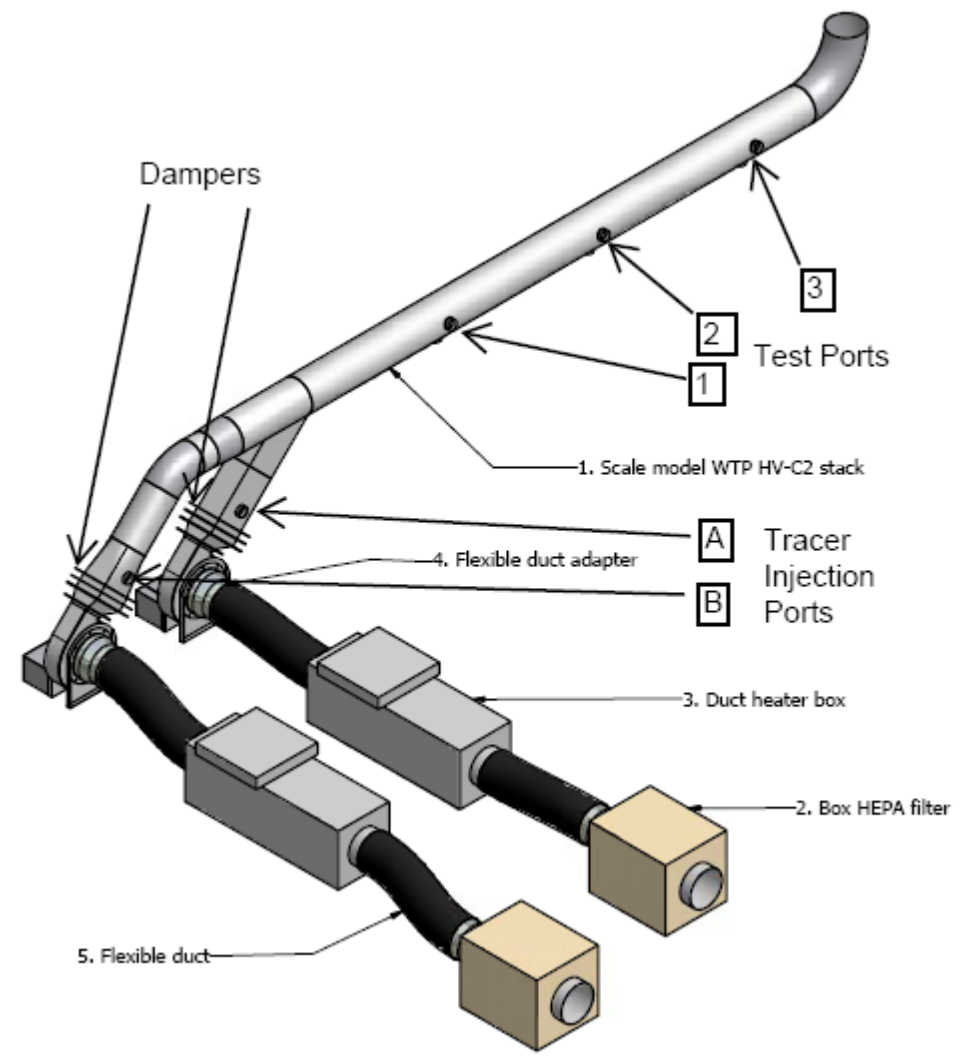

Figure 1.2. Scale Model Tested by Glissmeyer and Droppo (2007)

Table 1.1. Comparison of Model and Actual Stack Dimensions

\begin{tabular}{lcc}
\hline Operating Parameters & Model & Bldg. 3410 \\
\hline Duct diameter at sampling probe & 12 in. & 40 in. \\
$\begin{array}{l}\text { Number of duct diameters from upstream duct junction } \\
\text { to sampling probe or test ports }\end{array}$ & $\begin{array}{c}\text { Port } 1-4.5 \\
\text { Port 2 }-9.5 \\
\text { Port 3 - 14.5 }\end{array}$ & 16 \\
$\begin{array}{l}\text { Number of duct diameters from sampling probe or test } \\
\text { ports to downstream bend }\end{array}$ & Port 3 - 2.25 & 3 \\
$\begin{array}{l}\text { Discharge diameter } \\
\text { Number of operating fans }\end{array}$ & 12 in. & 32 in. \\
Total available fans & 1 and 2 & 2 \\
\hline
\end{tabular}




\subsection{Testing Strategy}

The velocity uniformity test results from the model stack are an important factor in the applicability of the model stack results to any other stack. Table 2.1 lists the results from the velocity uniformity test conducted on the model using Test Ports 2 and 3 with both one and two operating fans. The average velocity uniformity ( $\% \mathrm{COV})$ results were $4.8 \% \mathrm{COV}$ and $4.9 \% \mathrm{COV}$ for one and two operating fans, respectively. The most applicable test results for comparison with the 3410 Building exhaust system are the scale model results from Test Port 3 when both fans were running. The average velocity uniformity for these conditions was $4.7 \% \mathrm{COV}$. Therefore, the acceptance range for velocity uniformity results for the 3410 Building exhaust is from 0 to $9.7 \% \mathrm{COV}^{(\mathrm{a})}$ for the results from the $\mathrm{HV}-\mathrm{C} 2$ scale model to be considered applicable.

Table 2.2 shows calculations of the acceptable range of the diameter $\times$ velocity criterion that also determines the applicability of the scale-model results to the actual stacks. The product of duct diameter times air velocity during the tests with typical flow rates $(\mathrm{DV}=96,000)$ was within the acceptable factor of six of the scale model's DV product $(32,556 \times 6=195,336)$ for two operating fans. Table 2.2 also includes the Reynolds number for the scale tests and the building stack tests. In all cases, the Reynolds numbers are greater than 10,000, which is another criterion for applying the scale model results to the building stack.

Table 2.1. List of HV-C2 Velocity Uniformity Test Results with Dampers Installed (from Glissmeyer and Droppo 2007)

\begin{tabular}{|c|c|c|c|c|c|c|c|}
\hline $\begin{array}{l}\text { Test } \\
\text { Port }\end{array}$ & $\begin{array}{c}\text { Operating } \\
\text { Fans }\end{array}$ & $\begin{array}{l}\text { Run } \\
\text { No. }\end{array}$ & $\begin{array}{l}\text { Control } \\
\text { Damper } \\
\text { Setting } \\
\text { (degrees) }\end{array}$ & $\begin{array}{c}\text { Back Flow } \\
\text { Damper Setting } \\
\text { (degrees) }\end{array}$ & $\begin{array}{c}\text { Flow } \\
\text { Rate cfm }\end{array}$ & $\begin{array}{c}\text { Velocity } \\
\text { fpm }\end{array}$ & $\% \mathrm{COV}$ \\
\hline 2 & $\mathrm{~A}$ & VT-16 & 90 & 70 & 973 & 1239 & 3.6 \\
\hline 2 & B & VT-19 & 90 & 70 & 977 & 1244 & 6 \\
\hline 3 & A & VT-17 & 90 & 70 & 1002 & 1276 & 3.4 \\
\hline \multirow[t]{2}{*}{3} & B & VT-18 & 90 & 70 & 959 & 1221 & 6 \\
\hline & & & & Average & 977.8 & 1245.0 & 4.8 \\
\hline 2 & $A \& B$ & VT-13 & 90 & 70 & 2094 & 2666 & 6.1 \\
\hline 2 & $A \& B$ & VT-23 & 90 & 70 & 2132 & 2715 & 5.1 \\
\hline 2 & $A \& B$ & VT-24 & 90 & 70 & 2126 & 2706 & 4.4 \\
\hline 3 & $A \& B$ & VT-14 & 90 & 70 & 2117 & 2696 & 4.4 \\
\hline 3 & $A \& B$ & VT-21 & 90 & 70 & 2136 & 2720 & 5.1 \\
\hline \multirow[t]{2}{*}{3} & $A \& B$ & VT-22 & 90 & 70 & 2180 & 2775 & 4.5 \\
\hline & & & & Average & 2130.8 & 2713.0 & 4.9 \\
\hline
\end{tabular}

(a) $4.7 \%+/-5.0 \%=0 \%-9.7 \%$ (considering only positive values). 
Table 2.2. Ranges of Acceptable Diameter $\times$ Velocity Values and Reynolds Numbers

\begin{tabular}{ccccccc}
\hline Stack & $\begin{array}{c}\text { Diameter } \\
(\text { in. })\end{array}$ & Configuration & $\begin{array}{c}\text { Mean Velocity } \\
(\mathrm{fpm})\end{array}$ & $\begin{array}{c}\mathrm{D} \times \mathrm{V} \\
(\mathrm{in} . \times \mathrm{fpm})\end{array}$ & $\begin{array}{c}\text { Maximum } \\
6 \times(\mathrm{D} \times \mathrm{V})\end{array}$ & $\begin{array}{c}\text { Reynolds } \\
\text { Number }\end{array}$ \\
\hline Model & 12 & One Fan & 1245 & 14,940 & 89,640 & $1.3 \mathrm{E}+05$ \\
Model & 12 & Two Fans & 2713 & 32,556 & 195,336 & $2.8 \mathrm{E}+05$ \\
3410 & 40 & Two Fans & 2400 & 96,000 & & $8.3 \mathrm{E}+05$ \\
\hline
\end{tabular}

Table 2.3 lists the minimum matrix of tests needed for the 3410 Building Filtered Exhaust Stack. Also included in the list are the optional tests that may be required if the applicable criteria for velocity uniformity and diameter/velocity product were not met as presented above.

Table 2.3. Minimum Test Runs for 3410 Building Qualification

\begin{tabular}{|c|c|c|c|c|c|c|c|}
\hline \multicolumn{4}{|c|}{ Test Configuration } & \multicolumn{4}{|c|}{ Estimated Number of Test Runs } \\
\hline Fans & \# & $\begin{array}{c}\text { Injection } \\
\text { Port }\end{array}$ & Test Port & $\begin{array}{l}\text { Flow } \\
\text { Angle }\end{array}$ & Velocity & $\begin{array}{l}\text { Gas Tracer } \\
\text { (optional) }^{(a)}\end{array}$ & $\begin{array}{c}\text { Particle } \\
\text { Tracer } \\
\text { (optional) }\end{array}$ \\
\hline $\begin{array}{l}\text { Maximum } \\
\text { flow rate }\end{array}$ & 1 & Junction & At Probe & 2 & 2 & 7 & 2 \\
\hline $\begin{array}{l}\text { Minimum } \\
\text { flow rate }\end{array}$ & 2 & Junction & At Probe & 1 & 1 & 1 & 1 \\
\hline \multicolumn{4}{|c|}{ Total } & 3 & 3 & 8 & 3 \\
\hline \multicolumn{4}{|c|}{ Grand Total } & \multicolumn{4}{|c|}{17} \\
\hline
\end{tabular}

(a) Five of the seven runs involve injecting the tracer gas in the four corners and center of the cross section at the injection location. The two additional runs are replicates of the test with the worst-case result. 


\subsection{Testing Methods}

The testing methods for the confirmatory tests conducted at the 3410 Building stack are outlined in this section. Per the requirement outlined in Section 1, only the flow angle and velocity uniformity tests were conducted on the actual stack. Tracer testing on the actual stack is not currently anticipated.

Figure 3.1 shows the layout of the 3410 duct at the location of the air sampling probe and test ports used in this testing. Figure 3.2 is a photo of the stack interior taken with the inspection hatch removed. The photo is looking downstream in the stack, and shows the shrouded nozzle and flow sensor that make up the sample probe assembly.

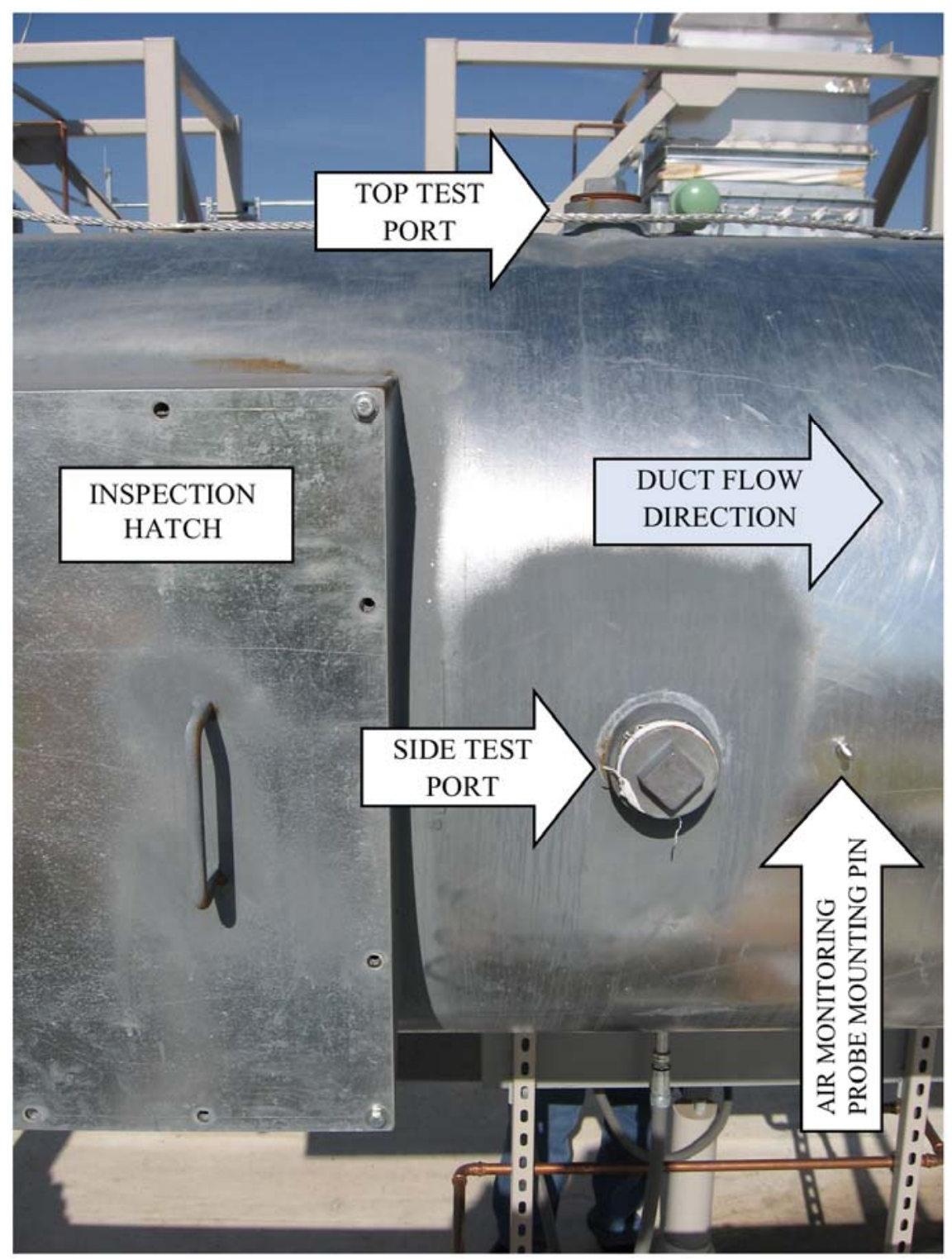

Figure 3.1. Layout of Test Ports and Other Duct Features at the 3410 Stack 


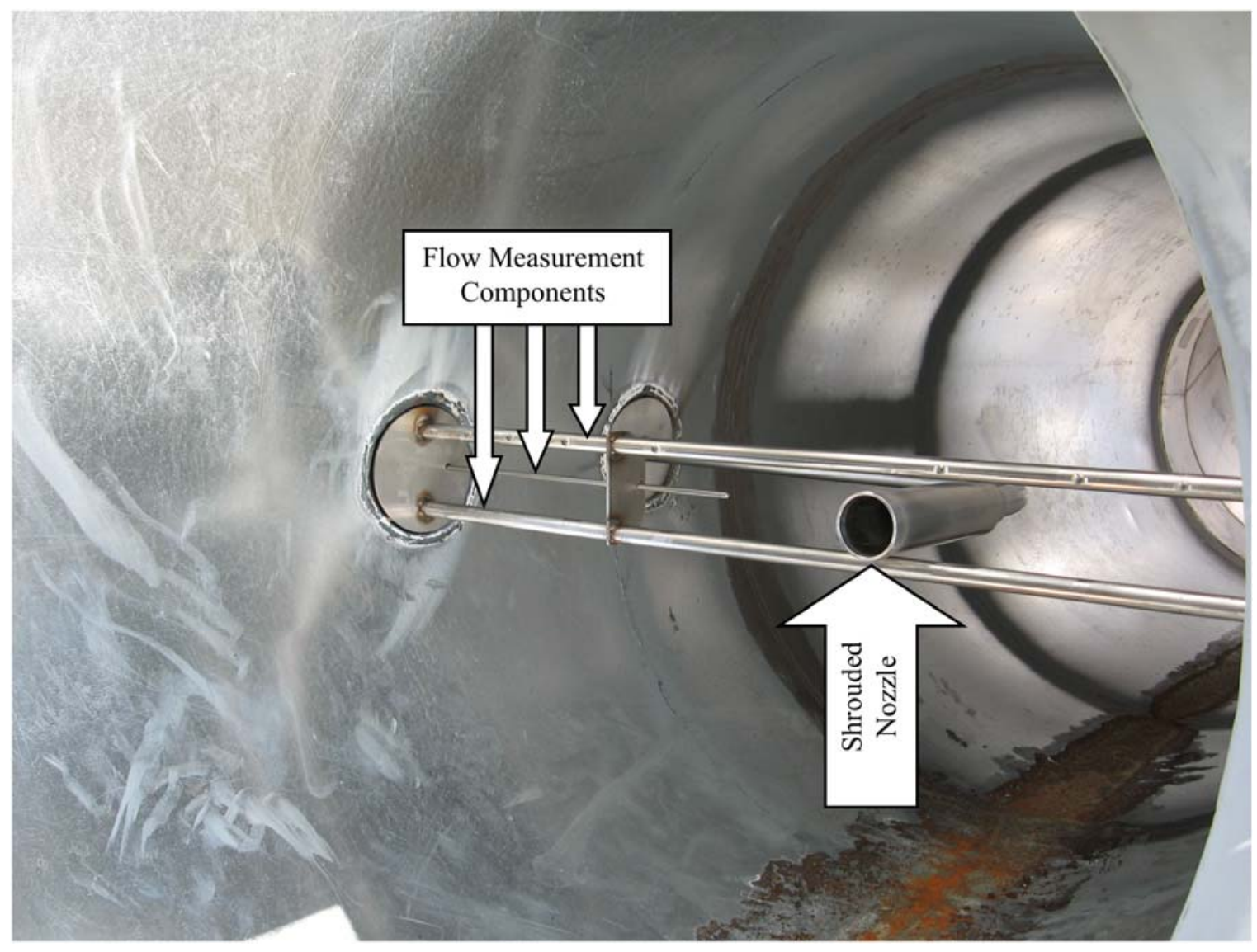

Figure 3.2. Air Monitoring Probe Assembly

\subsection{Flow Angle Test}

The air velocity vector approaching the sample nozzle should be aligned with the axis of the nozzle within an acceptable deviation angle so that the sample extraction performance is not degraded. The test method to determine the air velocity vector is based on 40 CFR 60, Appendix A, Method 1, Section 11.4, "Verification of the Absence of Cyclonic Flow." The term "flow angle" refers to the average angle between the velocity vector of the flow in the duct and the axis of the sampling nozzle. For the stack testing activities, the flow angle was measured at an array of 17 points in a cross pattern in the cross section of the duct. One line of measurement points was aligned with the sampling probe assembly (across the east-west diameter of the duct). The other line of measurement points was perpendicular to the sampling probe assembly (across the top-bottom diameter of the duct). The number and distance between the measurement points is based on the U.S. Environmental Protection Agency's (EPA's) method in 40 CFR 60, Appendix A, Method 1. The criterion for acceptance from the flow angle test is that the average angle must be $<20^{\circ}$.

The flow angle measurements were made using an S-type Pitot tube (Dwyer Instruments, 160S-72, Michigan City, IN) attached by flexible tubing to a slant-tube manometer (Dwyer Instruments, 400-5) and an angle-indicating device attached to the sampling port as shown in Figure 3.3 and Figure 3.4. For this test, the S-type Pitot tube was rotated so that the planes of the two openings at the tip of the tube were parallel to the flow in the duct. The Pitot tube is considered perpendicular to the flow in this position. 
The large metal plate in Figure 3.3 is the angle-indicating device. It has markings at every degree from -30 degrees to 30 degrees. When the pressures on both tubes of the S-type Pitot tube were equal (as indicated by the manometer), the angle shown on the angle-indicating device is recorded as the reading. Figure 3.4 shows the manometer mounted on the inspection hatch cover at the 3430 Building, which has a configuration similar to the 3410 Building. The PNNL operating procedure EMS-JAG-05 and the Test Instruction TI-STMON-009 were used to conduct this test.

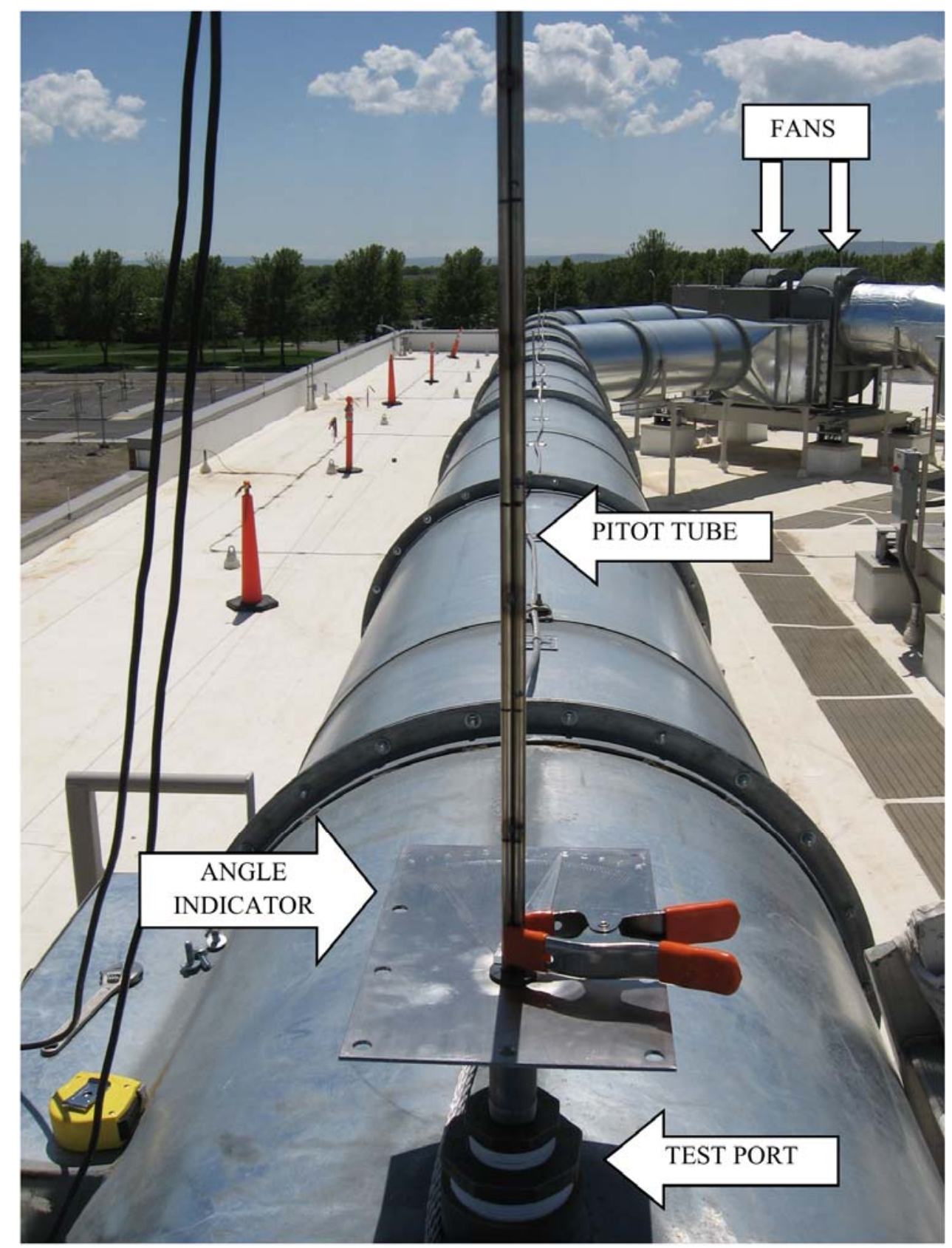

Figure 3.3. Flow Angle Indicator and Pitot Tube Installed on 3410 Stack 


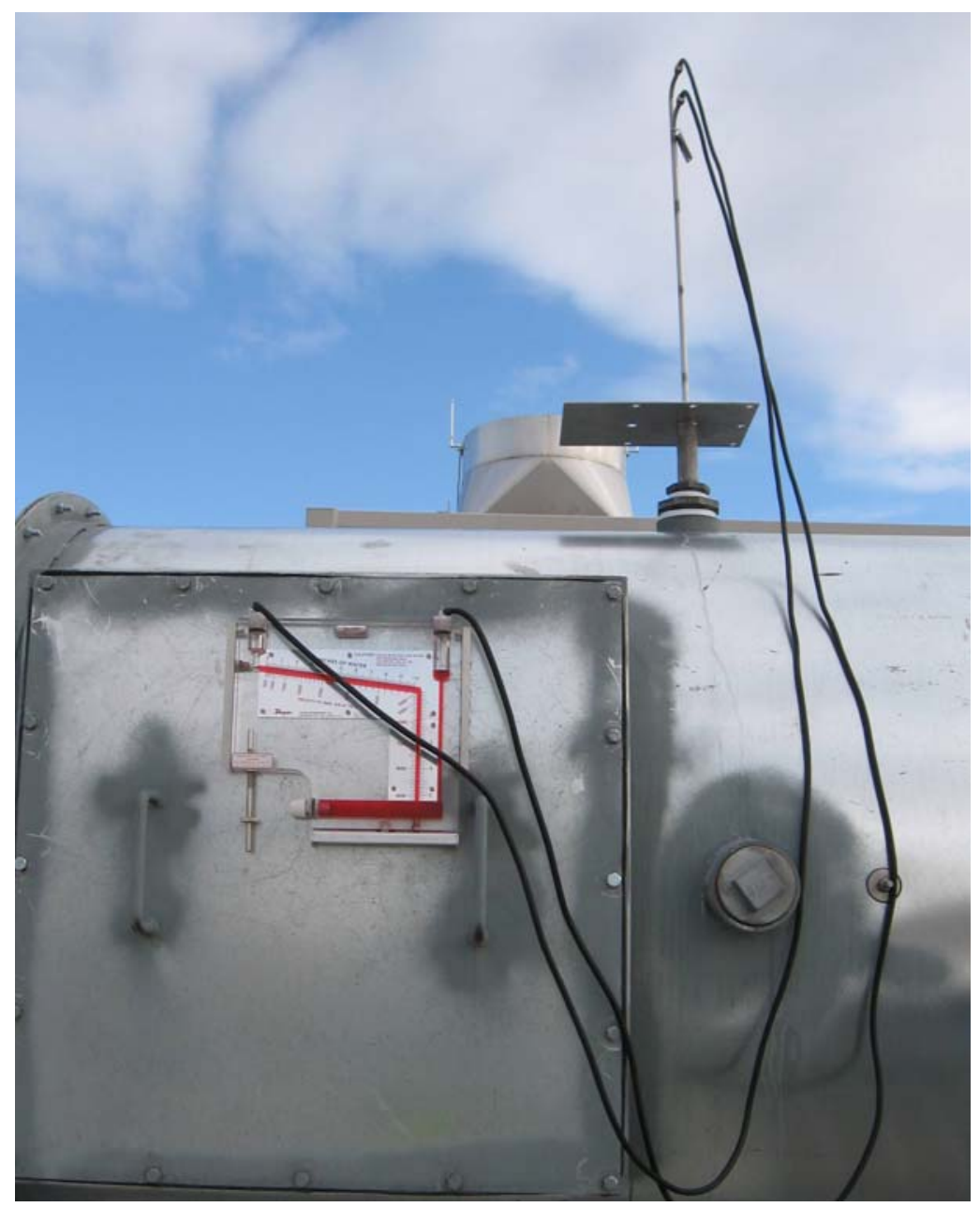

Figure 3.4. Slant Tube Manometer on 3430 Inspection Hatch Cover

\subsection{Velocity Uniformity Test}

The uniformity of air velocity at the stack monitoring location indicates the degree to which the momentum in the stack is well-mixed. The method used to conduct the velocity uniformity tests was based on 40 CFR 60, Appendix A, Method 1. The measurement grid used in the velocity uniformity tests was the same as the grid used for the flow angle test. In general, the criterion for acceptance from the velocity uniformity test is that the COV should be less than $20 \%$.

The air velocity was measured three times at each of the 17 grid points across the cross-section of the duct. The average of the three measurements for the center two thirds of the stack was used to determine the mean and standard deviation of the velocity across the cross-sectional plane. The coefficient of variance (also known as the percent relative standard deviation) was calculated as 100 times the standard deviation divided by the mean. For the previously conducted tests to be applicable to the 3410 Building exhaust stack, the \%COV from the 3410 velocity tests must be between 0 and $9.7 \% \mathrm{COV}$.

Each air velocity measurement was made using an S-type Pitot tube connected to a calibrated electronic manometer (GrayWolf, Zephyr II + , Shelton, CT) by flexible tubing. Duct air temperature measurements were made with a handheld thermal anemometer (TSI, Model 8360, Shoreview, MN). 
Figure 3.5 shows the equipment used for this test. In this test, the S-type Pitot tube was positioned so that the normal vector to one of the two openings at the tip was pointing in the same direction as the axis of the duct. The procedure EMS-JAG-04 and the test instruction TI-STMON-008 were followed to conduct this test.

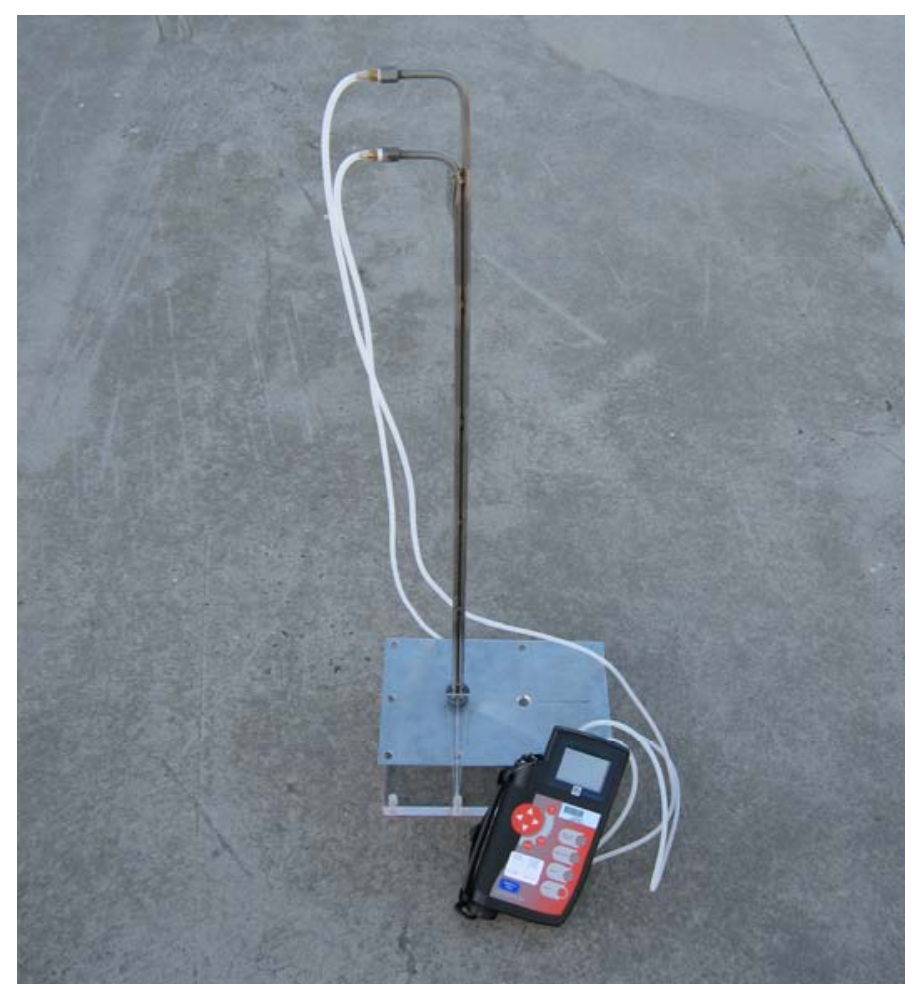

Figure 3.5. Electronic Manometer Connected to Pitot Tube

\subsection{Quality Assurance}

The Pacific Northwest National Laboratory Quality Assurance (QA) Program is based upon the requirements as defined in the U.S. Department of Energy Order 414.1C, Quality Assurance, and 10 CFR 830, Energy/Nuclear Safety Management, and Subpart A-Quality Assurance Requirements (a.k.a. the Quality Rule). PNNL has chosen to implement the following consensus standards in a graded approach:

- American Society of Mechanical Engineers (ASME) NQA-1-2000, Quality Assurance Requirements for Nuclear Facility Applications, Part 1, Requirements for Quality Assurance Programs for Nuclear Facilities (ASME 2000a)

- ASME NQA-1-2000, Part II, Subpart 2.7, Quality Assurance Requirements for Computer Software for Nuclear Facility Applications (ASME 2000b)

- ASME NQA-1-2000, Part IV, Subpart 4.2, Graded Approach Application of Quality Assurance Requirements for Research and Development (ASME 2000c). 
The procedures necessary to implement the requirements are documented in PNNL's standards-based management system called "How Do I...?" (HDI). ${ }^{\text {(a) }}$

The Stack Monitoring Project (STMON) implements a National Quality Assurance (NQA)-1-2000 Quality Assurance Program, graded on the approach presented in NQA-1-2000, Part IV, Subpart 4.2. The STMON Quality Assurance Manual (QA-STMON-0002 ${ }^{(\mathrm{b})}$ ) describes the technology life-cycle stages under the STMON Quality Assurance Plan (QA-STMON-0001 ${ }^{(\mathrm{c})}$ ). The technology life cycle includes the progression of technology development, commercialization, and retirement in process phases of basic and applied research and development $(\mathrm{R} \& \mathrm{D})$, engineering, and production and operation until process completion. The life cycle is characterized by flexible and informal QA activities in basic research, which becomes more structured and formalized through the applied R\&D stages.

- BASIC RESEARCH—Basic research consists of research tasks that are conducted to acquire and disseminate new scientific knowledge. During basic research, maximum flexibility is desired to allow the researcher the necessary latitude to conduct the research.

- APPLIED RESEARCH-Applied research consists of research tasks that acquire data and documentation necessary to make sure that results can be satisfactorily reproduced. The emphasis during this stage of a research task is on achieving adequate documentation and controls necessary to be able to reproduce results.

- DEVELOPMENTAL WORK-Developmental Work consists of research tasks moving toward technology commercialization. These tasks still require a degree of flexibility, and there is still a degree of uncertainty that exists in many cases. The role of quality on Developmental Work is to make sure that adequate controls to support movement into commercialization exist.

- RESEARCH AND DEVELOPMENT SUPPORT ACTIVITIES-Support activities are those that are conventional and secondary in nature to the advancement of knowledge or development of technology, but allow the primary purpose of the work to be accomplished in a credible manner. An example of a support activity is controlling and maintaining documents and records. The level of quality for these activities is the same as for developmental work.

The work described in this report has been completed under the QA Technology level of Development Work. STMON addresses internal verification and validation activities by conducting an independent technical review of the final data report in accordance with STMON's procedure QA-STMON-601, ${ }^{\text {(d) }}$ Document Preparation and Change. This review verifies that the reported results are traceable, that inferences and conclusions are soundly based, and that the reported work satisfies the Test Plan objectives.

The tests were conducted according to an approved Test Plan and Test Instructions. Data transcription and calculations were independently reviewed.

(a) System for managing the delivery of laboratory-level policies, requirements, and procedures.

(b) QA-STMON-0002, Rev. 0. January 2, 2010. "Pacific Northwest National Laboratory Stack Monitoring Project Quality Assurance Manual," Pacific Northwest National Laboratory, Richland, Washington.

(c) QA-STMON-0001, Rev. 0. January 2, 2010. "Pacific Northwest National Laboratory Stack Monitoring Project Quality Assurance Plan," Pacific Northwest National Laboratory, Richland, Washington.

(d) QA-STMON-0601, Rev. 0. January 2, 2010. "Document Preparation and Change," Pacific Northwest National Laboratory, Richland, Washington. 


\subsection{Stack Testing Results}

Independent reviews were performed to verify the data transcription and calculations. The final data sheets are included in Appendix A.

The duct diameters that were field measured at the test ports were found to be 40.0 in as listed in Table 4.1. The distance from the test ports to the nearest upstream disturbance (the junction of the ducts from the two fans) was $53.5 \mathrm{ft}$. The tests were conducted at 16 duct diameters (DIA = linear distance divided by duct diameter) downstream of the duct junction. In comparison, the scale model tests were conducted at ports located 4.45 DIA, 9.47 DIA, and 14.5 DIA.

Table 4.1. 3410 Duct Depth Measurements

\begin{tabular}{cc}
\hline $\begin{array}{c}\text { Direction across } \\
\text { duct }\end{array}$ & $\begin{array}{c}\text { Measured Duct } \\
\text { Diameter, in. }\end{array}$ \\
\hline Vertical & 40.0 \\
Horizontal & 40.0 \\
\hline
\end{tabular}

\subsection{Velocity Uniformity}

Table 4.2 lists the results for the velocity uniformity tests performed on the 3410 Building exhaust duct. The conditions for the velocity uniformity test runs (VTs) included a typical low-flow condition with all fume hood sashes closed and a typical high-flow condition with all fume hood sashes open as well as a condition in which the fans were manually set to a low flow. The flow rate was measured with the Zephyr II+ results in actual cubic feet per minute (acfm) whereas the airflow displayed in the air sampling cabinet is in standard cubic feet per minute ( $\mathrm{scfm})$. In all cases tested, the results were well within the general criterion of COV values less than $20 \%$. The average of the four tests was $3.9 \% \mathrm{COV}$, which compares well with the $4.7 \%$ COV measured for the most similar (geometric and operational) condition represented by the model test. COV values were within the acceptance criterion derived in Section $2(<9.7 \%$ COV $)$ for verifying that the 3410 Building Filtered Exhaust Stack configuration is represented by the model tests of Glissmeyer and Droppo (2007). The completed data sheets from these three tests are available in Appendix A.

Table 4.2. Summary of Velocity Uniformity Tests

\begin{tabular}{ccccc}
\hline Fan Operating Configuration & Run Nos. & $\begin{array}{c}\text { Measured } \\
\text { acfm }\end{array}$ & $\begin{array}{c}\text { Airflow Displayed in } \\
\text { Sampling Cabinet scfm }\end{array}$ & \% COV \\
\hline 2 Fans, Lab hood sashes closed & VT-1 & 19,759 & 17,910 & 3.6 \\
2 Fans, Lab hood sashes open & VT-2 & 21,136 & 19,325 & 4.3 \\
2 Fans, Lab hood sashes open & VT-3 & 20,451 & 19,050 & 4.1 \\
2 Fans, manually set to low rpm & VT-4 & 12,351 & 10,800 & 3.4 \\
\hline
\end{tabular}




\subsection{Flow Angle}

Table 4.2 lists the results for the flow angle test runs (FAs) performed on the 3410 Building exhaust duct. The average flow angle of $2.8^{\circ}$ is acceptable as it is well within the criterion of average flow angle values less than $20^{\circ}$. The completed data sheets from these three tests are available in Appendix A.

Table 4.3. Summary of Flow Angle Tests

\begin{tabular}{cccc}
\hline Fan Operating Configuration & Run Nos. & $\begin{array}{c}\text { Airflow Displayed in } \\
\text { Sampling Cabinet scfm }\end{array}$ & $\begin{array}{c}\text { Mean Absolute } \\
\text { Flow Angle }\end{array}$ \\
\hline 2 Fans, Lab hood sashes closed & FA-1 & 17,975 & 3.1 \\
2 Fans, Lab hood sashes open & FA-2 & 18,350 & 2.7 \\
2 Fans, manually set to low rpm & FA-3 & 10,800 & 2.6 \\
\hline
\end{tabular}




\subsection{Conclusions}

Velocity uniformity tests were performed on the 3410 Building Filtered Exhaust Stack during May 2010 and show an acceptable level of agreement with the results of the scale-model tests performed previously (Glissmeyer and Droppo 2007). The previous tests of velocity uniformity had COV values of $4.7 \% \mathrm{COV}$, which allows the results of the actual stack to be up to $9.7 \% \mathrm{COV}$. The 3410 velocity tests compared well with the scale-model results with an average value of $3.9 \% \mathrm{COV}$. Consequently, the location of the air sampling probe meets the qualification criteria given in ANSI/HPS-1999. The gas and particle tracer qualification results of the scale model apply equally to the full-sized stack. The results from Glissmeyer and Droppo (2007) are included in Appendix B of this report. The results for the flow angle test on the 3410 Building Filtered Exhaust Stack also show compliance with the flow angle criterion. 



\subsection{References}

10 CFR 830, Subpart A. 2008. "Quality Assurance Requirements." Code of Federal Regulations, U.S. Department of Energy.

40 CFR 60, Appendix A, Method 1. 2008. "Sample and Velocity Traverses for Stationary Sources." Code of Federal Regulations, U.S. Environmental Protection Agency.

40 CFR 61, Subpart H. 2002. "National Emission Standard For Emissions of Radionuclides other than Radon from Department of Energy Facilities." Code of Federal Regulations, U.S. Environmental Protection Agency.

ASME-American Society of Mechanical Engineers. 2000a. NQA-1-2000, Quality Assurance Requirements for Nuclear Facility Applications, Part 1, "Requirements for Quality Assurance Programs for Nuclear Facilities." New York, New York.

ASME-American Society of Mechanical Engineers. 2000b. NQA-1-2000, Part II, Subpart 2.7, "Quality Assurance Requirements for Computer Software for Nuclear Facility Applications." New York, New York.

ASME_-American Society of Mechanical Engineers. 2000c. NQA-1-2000, Part IV, Subpart 4.2, "Graded Approach Application of Quality Assurance Requirements for Research and Development." New York, New York.

ANSI/HPS - American National Standards Institute/Health Physical Society. 1999. Sampling and Monitoring Releases of Airborne Radioactive Substances from the Stack and Ducts of Nuclear Facilities. N13.1-1999. Health Physics Society, McLean, Virginia.

DOE Order 414.1C. "Quality Assurance.” U.S. Department of Energy, Washington, D.C.

Glissmeyer JA and JG Droppo. 2007. Assessment of the HV-C2 Stack Sampling Probe Location. PNNL-16611, Pacific Northwest National Laboratory, Richland, Washington.

EMS-JAG-04. Rev. 2. 2009. Test to Determine Uniformity of Air Velocity at a Sampler Probe. Pacific Northwest National Laboratory, Richland, Washington.

EMS-JAG-05. Rev. 2. 2009. Test to Determine Flow Angle. Pacific Northwest National Laboratory, Richland, Washington.

TI-STMON-009. 2009. Flow Angle Test of Filtered Exhaust at 3410 Building. Pacific Northwest National Laboratory, Richland, Washington.

TI-STMON-008. 2009. Velocity Uniformity Test of Filtered Exhaust at 3410 Building. Pacific Northwest National Laboratory, Richland, Washington. 

Appendix A

Data Sheets 



\section{Appendix A: Data Sheets}

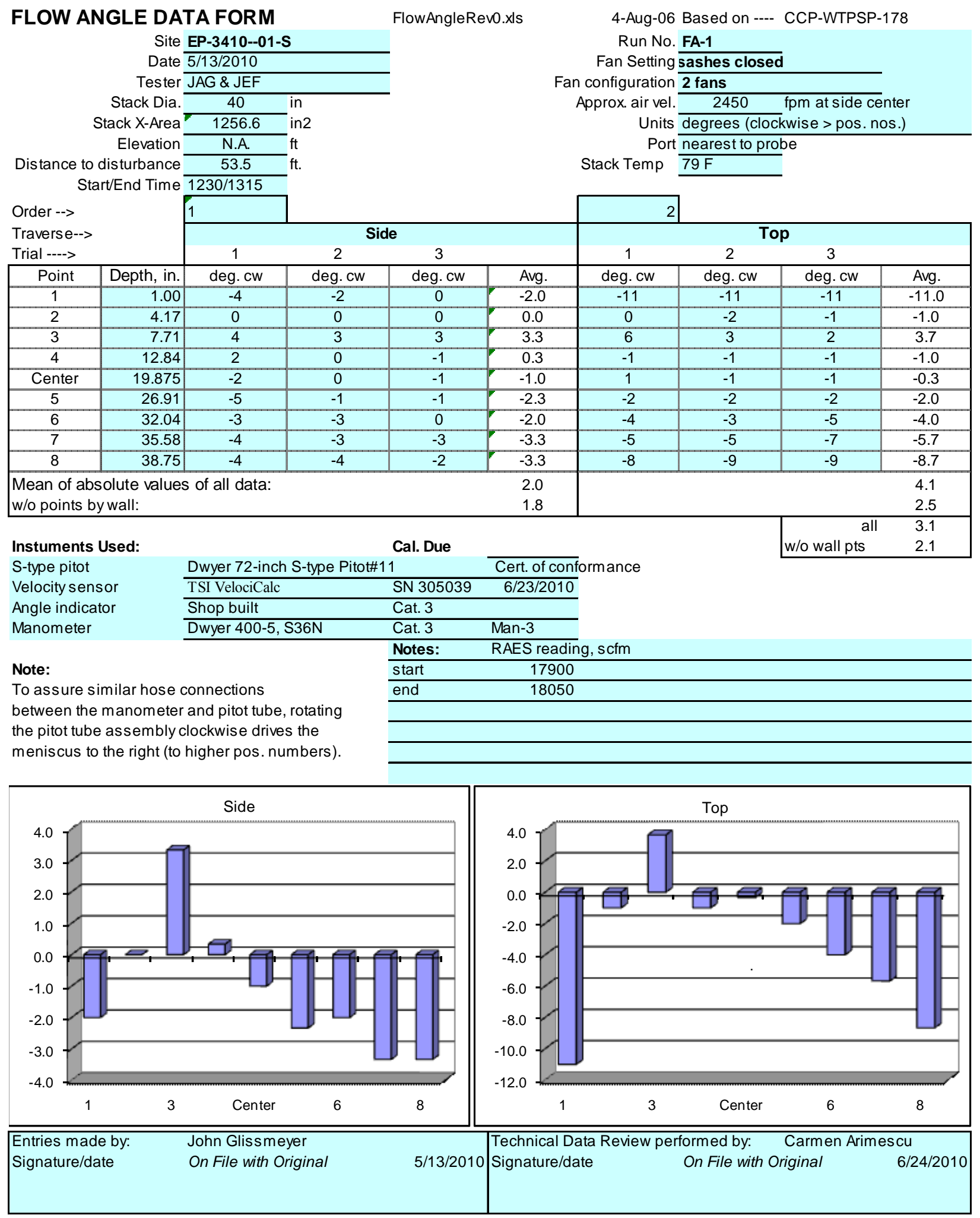


FLOW ANGLE DATA FORM

Site EP-3410--01-S

Date $5 / 14 / 2010$

Tester JAG \& JEF

Stack Dia.

Stack X-Area

Elevation N.A. $\mathrm{ft}$

Distance to disturbance $\frac{53.5}{\mathrm{ft}}$.

Start/End Time 1015/1100
FlowAngleRev0.xls

2nd

Order -->

Trial ---->

Trial --->
\begin{tabular}{|c|r|}
\hline Point & Depth, in \\
\hline 1 & 1.00 \\
\hline 2 & 4.17 \\
\hline 3 & 7.71 \\
\hline 4 & 12.84 \\
\hline Center & 19.875 \\
\hline 5 & 26.91 \\
\hline 6 & 32.04 \\
\hline 7 & 35.58 \\
\hline 8 & 38.75 \\
\hline
\end{tabular}

\begin{tabular}{|l|l}
\hline Side & \\
\hline &
\end{tabular}

Run No. FA-2

Fan Setting sashes open

Fan configuration 2 fans

Approx. air vel. $2630 \quad \mathrm{fpm}$ at top center

Units degrees (clockwise > pos. nos.)

Port nearest to probe

Stack Temp 79

Mean of absolute values of all data: w/o points by wall:

st

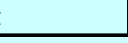

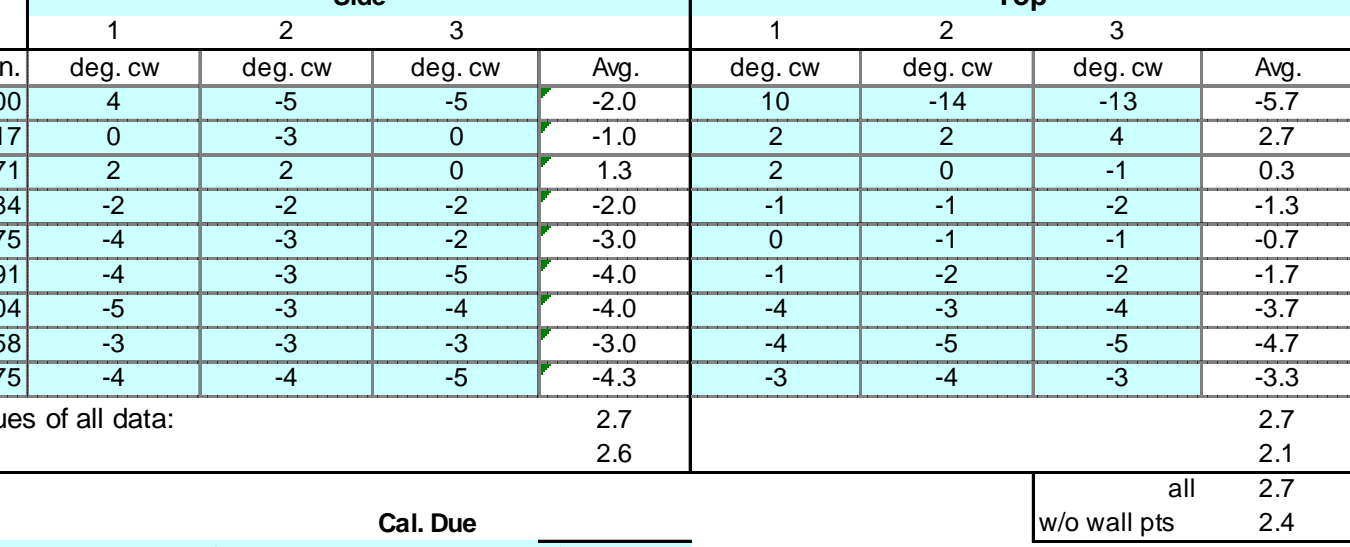

Instuments Used:

S-type pitot

Velocity sensor

Angle indicator

Manometer

Dwyer 72-inch S-type Pitot\#11

Cert. of conformance

SN $305039 \quad 6 / 23 / 2010$

TSI VelociCalc

Cat. 3

Dwyer 400-5, S36N

Cat. 3

Notes: RAES reading, scfm

Note:

To assure similar hose connections

between the manometer and pitot tube, rotating

the pitot tube assembly clockwise drives the

meniscus to the right (to higher pos. numbers).

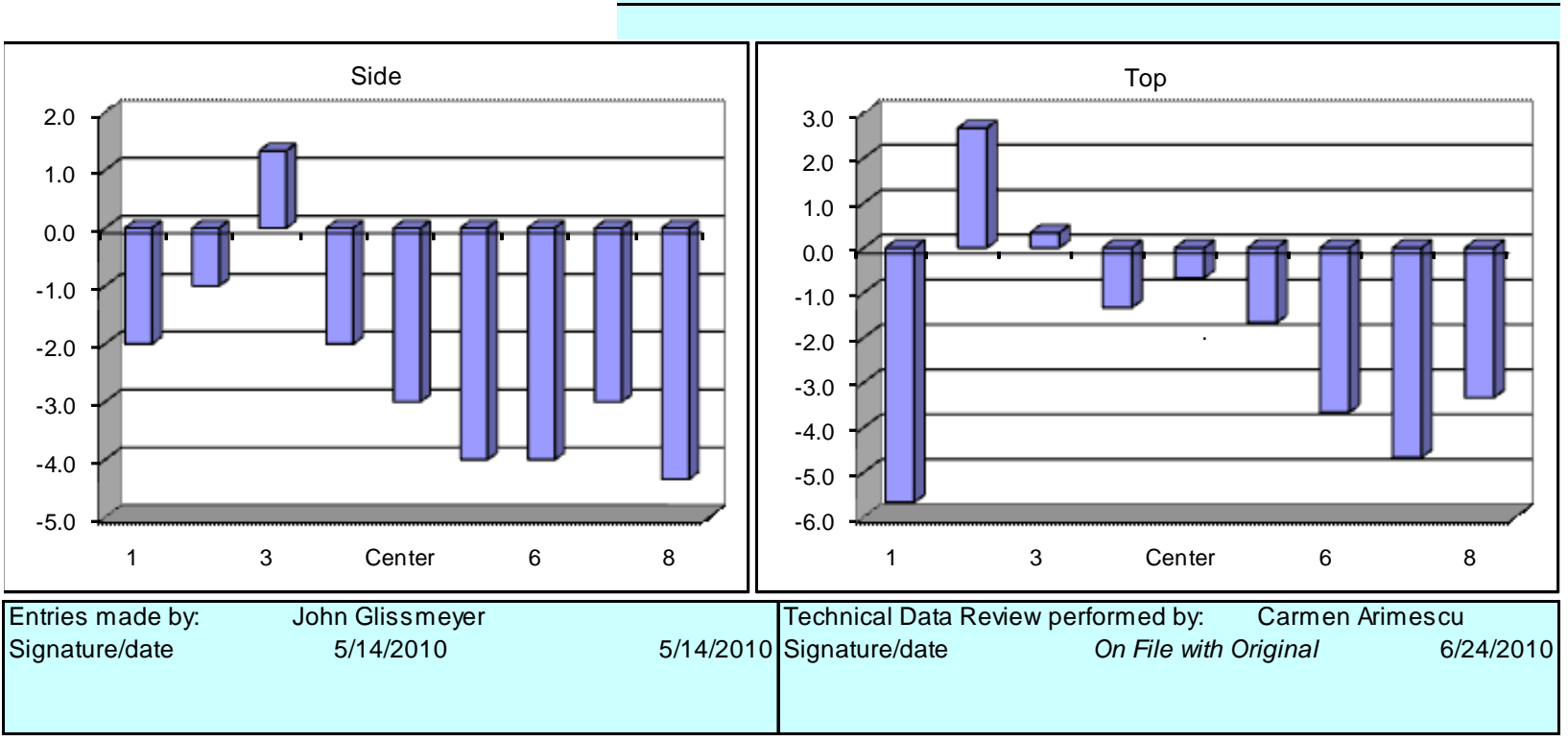


FLOW ANGLE DATA FORM

Site EP-3410--01-S

Date $5 / 14 / 2010$

Tester JAG \& JEF

Stack Dia.

Stack X-Area

Elevation N.A. $\mathrm{ft}$

Distance to disturbance $\frac{53.5}{\mathrm{ft}}$.

Start/End Time 1205/1225
FlowAngleRev0.xls

$1 \mathrm{st}$

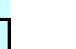

(nide

Order -->

Trial ---->

Trial ---->
\begin{tabular}{|c|r|}
\hline Point & Depth, in \\
\hline 1 & 1.00 \\
\hline 2 & 4.17 \\
\hline 3 & 7.71 \\
\hline 4 & 12.84 \\
\hline Center & 19.875 \\
\hline 5 & 26.91 \\
\hline 6 & 32.04 \\
\hline 7 & 35.58 \\
\hline 8 & 38.75 \\
\hline
\end{tabular}

1

4-Aug-06 Based on ---- CCP-WTPSP-178

Run No. FA-3

Fan Setting manual low

Fan configuration 2 fans

Approx. air vel. $1450 \quad \mathrm{fpm}$ at side center

Units degrees (clockwise $>$ pos. nos.)

Port nearest to probe

Mean of absolute values of all data:

w/o points by wall:

\begin{tabular}{ll|ll}
\cline { 2 - 3 } & Side & & Top \\
\hline
\end{tabular}

\begin{tabular}{|c|c|c|}
\hline deg. cw & deg. cw & deg. cw \\
\hline
\end{tabular}

\begin{tabular}{|c|c} 
& \\
\hline Avg. & d \\
\hline-2.7 & \\
\hline 0.0 & \\
\hline-0.7 & \\
\hline-2.3 & \\
-2.7 & \\
\hline-3.3 & \\
\hline-3.7 & \\
\hline-4.3 & \\
\hline-4.3 & \\
\hline 2.7 & \\
2.4 & \\
\hline
\end{tabular}

Instuments Used:

S-type pitot

Velocity sensor

Angle indicator

Manometer

4.17

\begin{tabular}{c|c}
-5 & -1
\end{tabular}

\begin{tabular}{c|c|}
\hline g. cw & deg. cw \\
\hline-1 & -2 \\
\hline 0 & 0 \\
\hline-2 & -1 \\
\hline-3 & -2 \\
\hline-3 & -3 \\
\hline-4 & -4 \\
\hline-4 & -5 \\
\hline-5 & -4 \\
\hline-4 & -4 \\
\hline
\end{tabular}

1

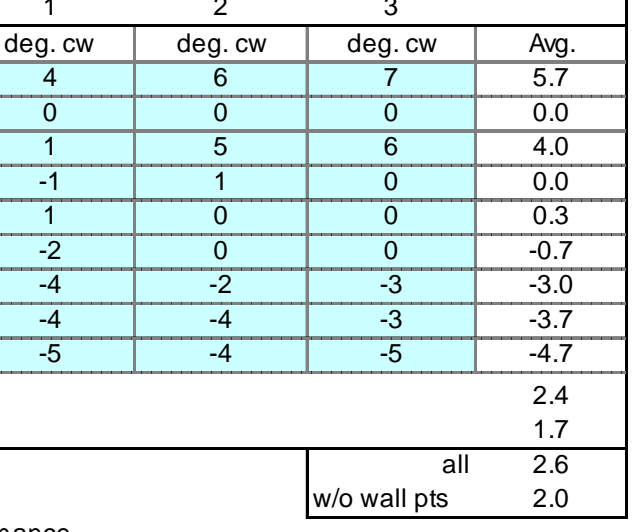

Top

Note:

To assure similar hose connections

between the manometer and pitot tube, rotating the pitot tube assembly clockwise drives the meniscus to the right (to higher pos. numbers).

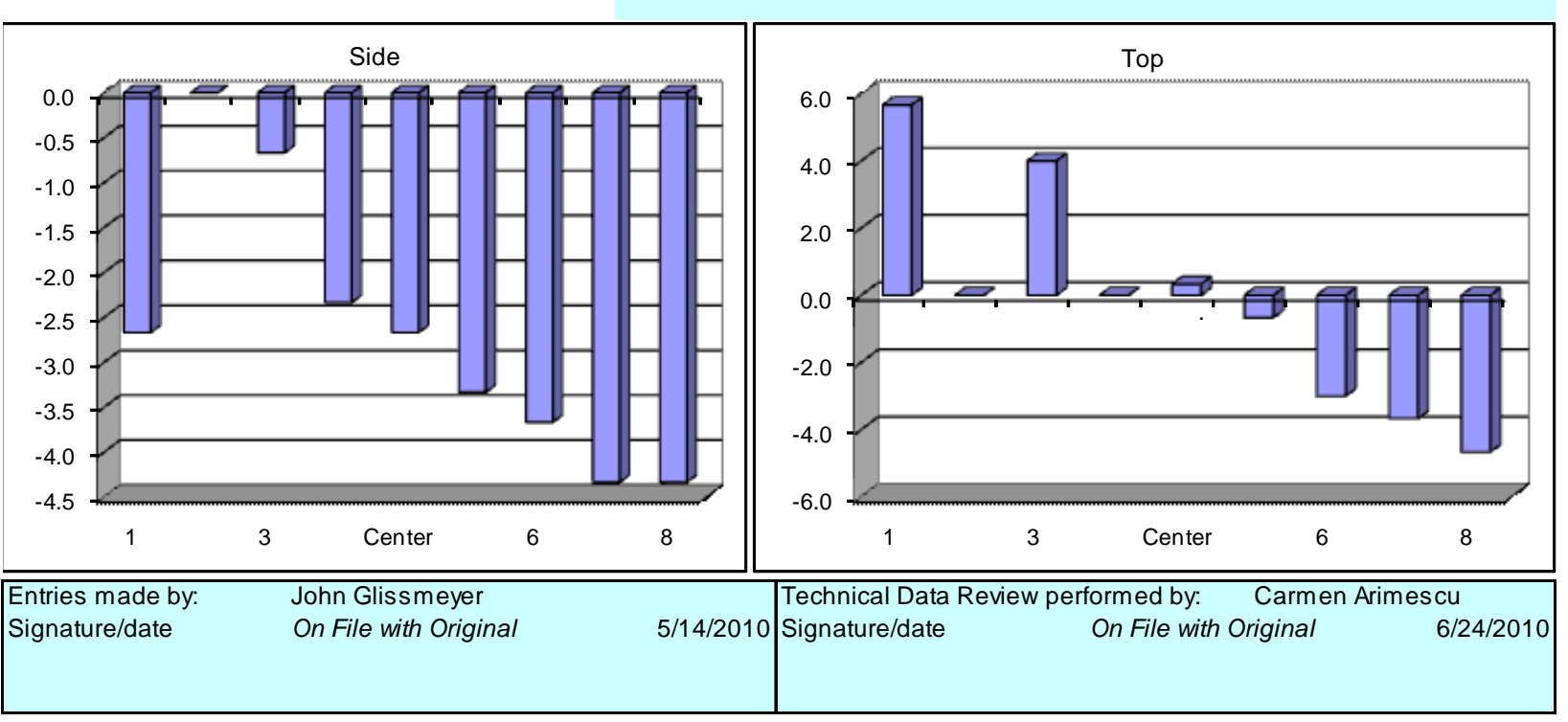




\section{VELOCITY TRAVERSE DATA FORM}

Site EP-3410-01-S

Date $\mathbf{5 / 1 3 / 1 0}$

Testers JAG \& JEF

Stack Dia.

Stack X-Area 1256.6 in.2

Test Port NEAREST TO PROBE

Distance to disturbance $53.5 \mathrm{ft}$.

Velocity units $\mathrm{ft} / \mathrm{min}$
Run No. VT-1

Fan Configuration 2 fans

Fan Setting sashes closed

Stack Temp

Start/End Time 1320/1505

Center $2 / 3$ from

Points in Center $2 / 3$

Pitot correction: 0.84
Order -->

Traverse-->

Trial ---->

\begin{tabular}{|r|r|}
\hline Point & Depth, in \\
\hline 1 & 1.00 \\
\hline 2 & 4.17 \\
\hline 3 & 7.71 \\
\hline 4 & 12.8 \\
\hline Center & 19.87 \\
\hline 5 & 26.9 \\
\hline 6 & 32.0 \\
\hline 7 & 35.58 \\
\hline 8 & 38.75 \\
\hline
\end{tabular}

Averages

\section{2nd}

$1 \mathrm{st}$

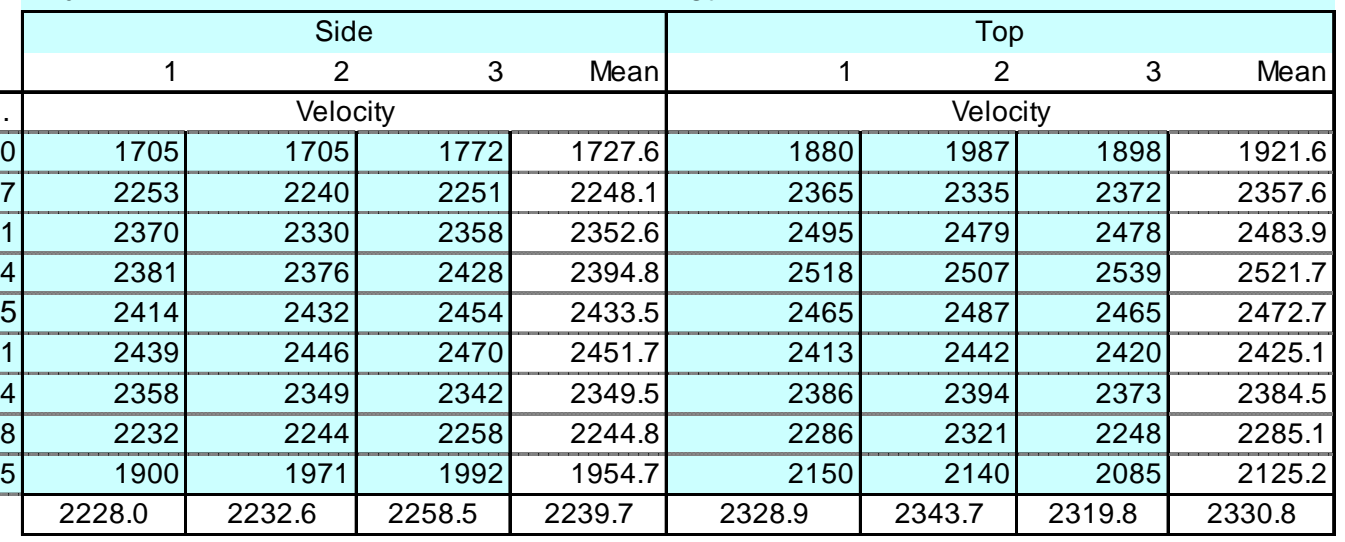

\begin{tabular}{|lrr|lrrr|}
\hline $\boldsymbol{A} I l$ & $\underline{\mathrm{ft} / \mathrm{min}}$ & Dev. from mean & Center 2/3 & Side & Top & All \\
Mean & 2285.3 & & Mean & 2353.6 & 2418.6 & 2386.1 \\
Min Point & 1727.6 & $-24.4 \%$ & Std. Dev. & 82.4 & 82.2 & 86.0 \\
MaxPoint & 2521.7 & $10.3 \%$ & COV as \% & 3.5 & 3.4 & $\mathbf{3 . 6}$ \\
\hline
\end{tabular}

Flow w/o C-Pt Vel Avg w/o C-Pt

Stack temp Equipment temp Ambient temp Stack static Ambient pressure Total Stack pressure Ambient humidity

\begin{tabular}{|c|c|l}
\multicolumn{1}{|c|}{ Start } & Finish & \\
\hline 80.7 & 82 & $F$ \\
\cline { 1 - 2 } N.A. & N.A. & F \\
\hline 80 & 85 & F \\
\hline 0.80 & 0.70 & mbars \\
\hline 1006 & 1005 & mbars \\
\hline 1007 & 1006 & mbars \\
\hline $25 \%$ & $21 \%$ & RH \\
\hline
\end{tabular}

Notes: $\quad$ RAES readings, $\mathrm{scfm}$

\begin{tabular}{lr}
\cline { 2 - 2 } start & 17870 \\
\hline end & 17950 \\
\hline
\end{tabular}

\begin{tabular}{lll} 
Instuments Used: & & Cal Due \\
\cline { 3 - 3 } Fisher Scientific & SN 90936818 & 9/29/2010 \\
\hline Zephyr II+ & SN 80355 & 9/18/2010 \\
\hline TSI Velocicalc & SN 305039 & 6/23/2010 \\
\hline Dwyer Pitot Tube & PN 1605-72 A304 & Cert. of Conf. \\
\hline
\end{tabular}

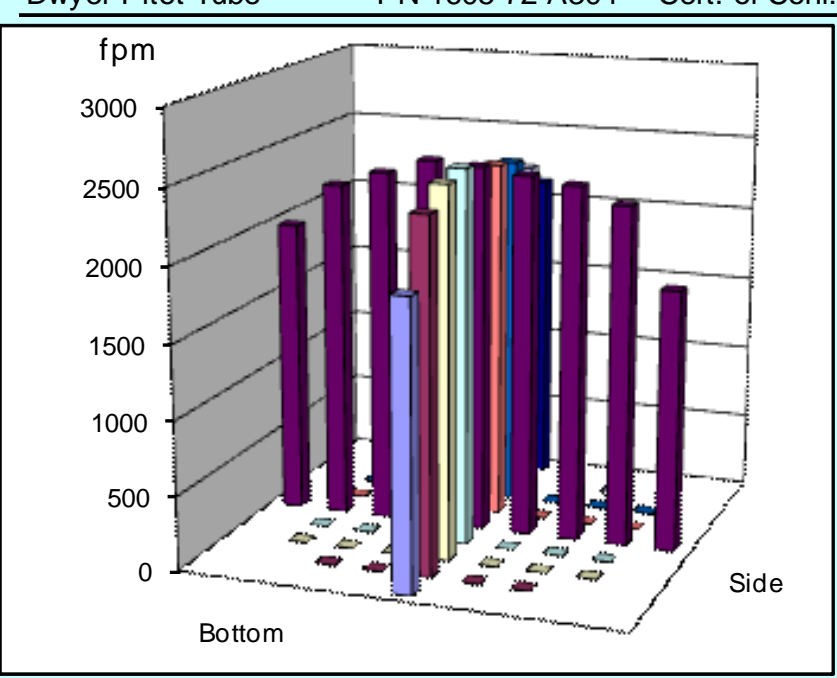

Entries made by: Julia Flaherty On File with Original
Technical Data Review performed by: 5/13/2010 Signature/date
$6 / 24 / 2010$ 


\section{VELOCITY TRAVERSE DATA FORM}

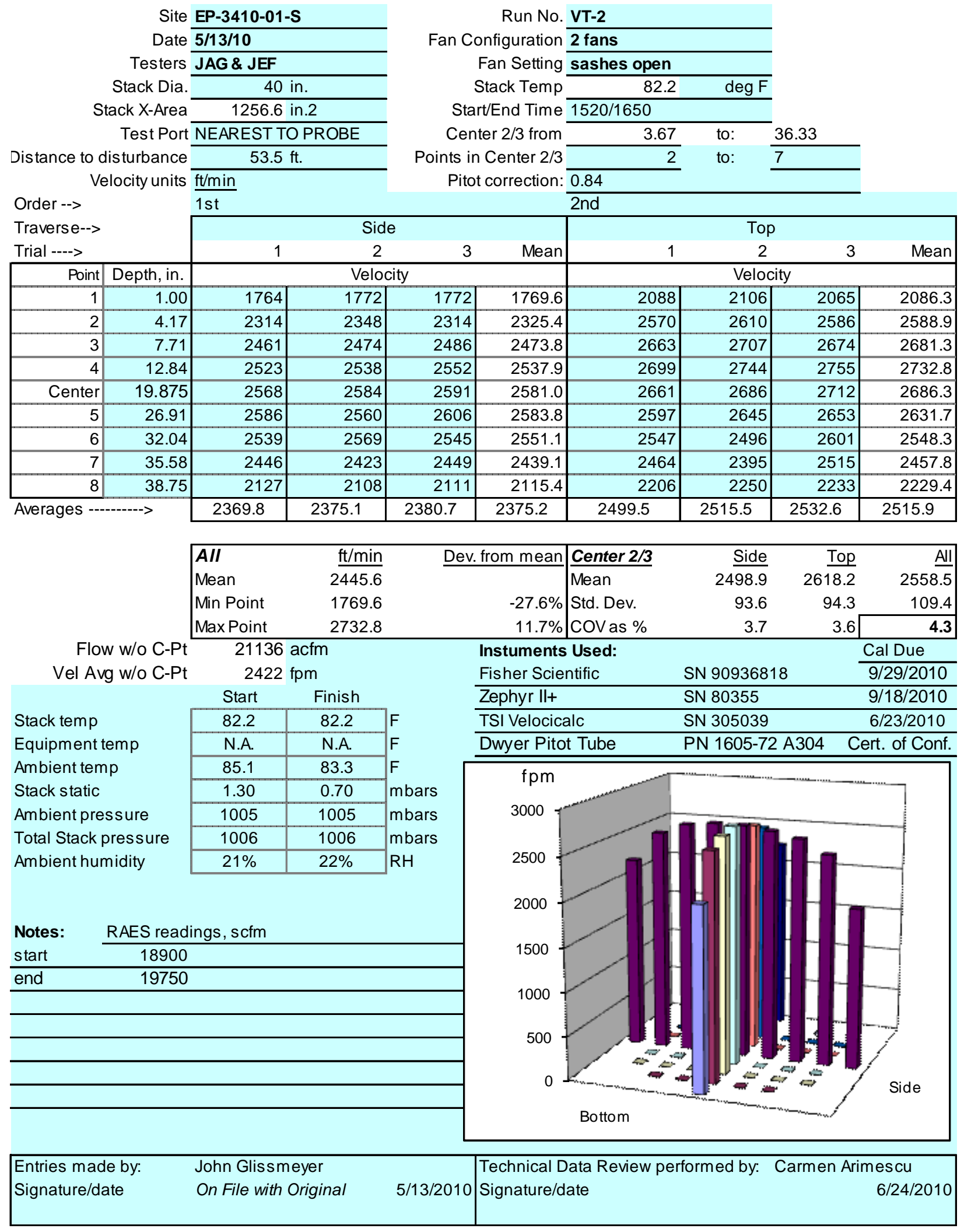




\section{VELOCITY TRAVERSE DATA FORM}

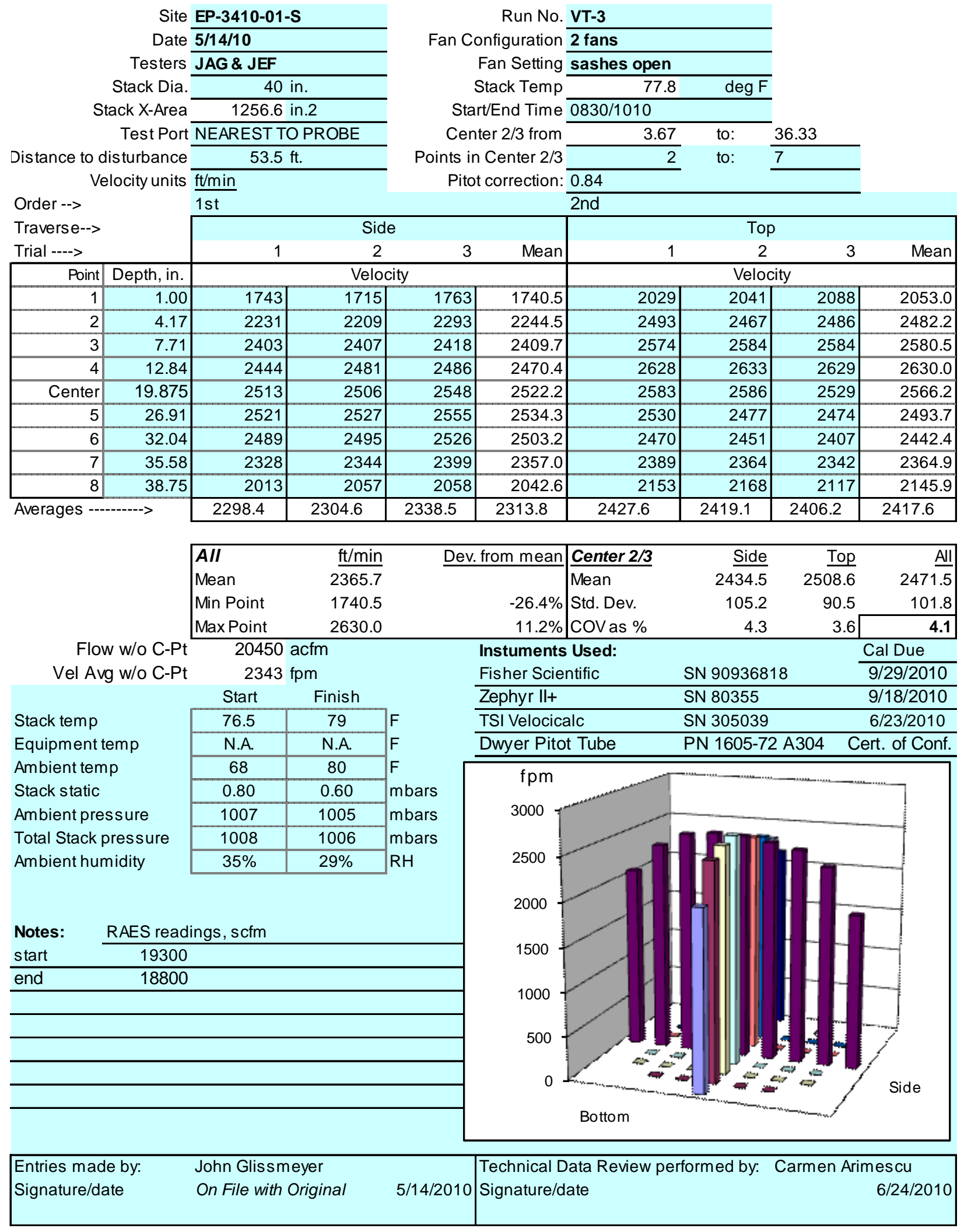




\section{VELOCITY TRAVERSE DATA FORM}

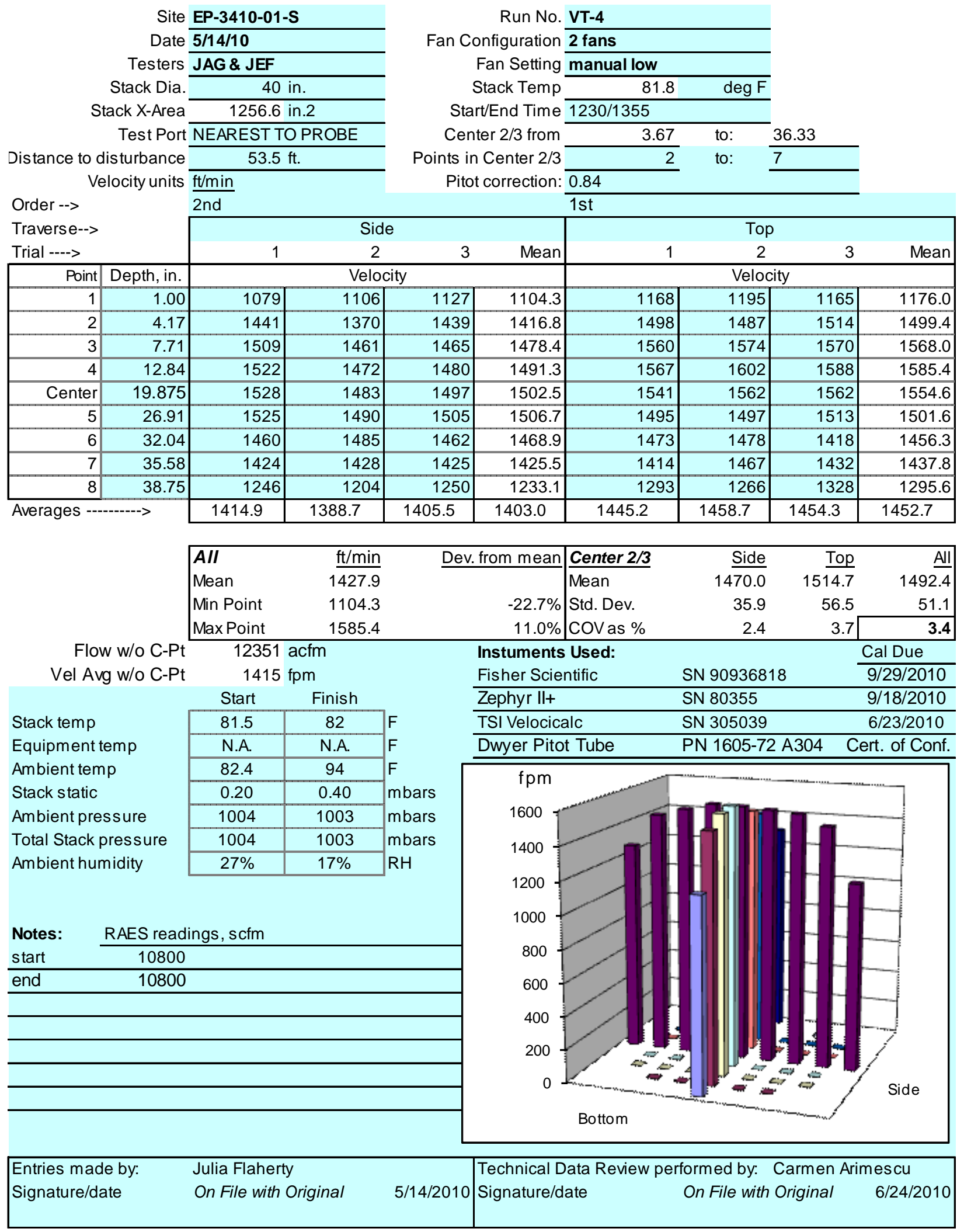





\section{Appendix B}

Applicable Qualification Results from the Model Stack 



\section{Appendix B: Applicable Qualification Results from the Model Stack}

These data are extracted from the report by Glissmeyer and Droppo (2007).

Table B.1 lists the gas-tracer uniformity tests conducted on the scale model with the dampers installed at the fan outlets. Only the data for Test Ports 2 and 3 are shown. The model Test Port 3 was just 1.5 duct diameters closer to the nearest upstream disturbance than the test ports on the 3410 Building Filtered Exhaust Stack. Therefore, the tracer uniformity results for the 3410 Building Filtered Exhaust Stack would likely be slightly more favorable relative to the acceptance criteria.

The $\% \mathrm{COV}$ was calculated for the measured gas concentration at the points in the center two-thirds area of the scale model stack. The percent deviation from the mean concentration was also calculated for any point in the measurement grid.

Table B.1. Summarized Results of Gas-Tracer Uniformity Tests with Dampers

\begin{tabular}{|c|c|c|c|c|c|c|c|c|}
\hline \multicolumn{2}{|c|}{ Injection Port } & $\begin{array}{c}\text { Operating } \\
\text { Fans }\end{array}$ & $\begin{array}{l}\text { Test } \\
\text { Port }\end{array}$ & Run No. & $\begin{array}{c}\text { Control } \\
\text { Damper } \\
\text { Setting } \\
\text { (degrees) }\end{array}$ & $\begin{array}{c}\text { Back Flow } \\
\text { Damper } \\
\text { Setting } \\
\text { (degrees) }\end{array}$ & $\begin{array}{c}\text { Center } \\
2 / 3 \% \\
\mathrm{COV} \\
\end{array}$ & $\begin{array}{c}\% \\
\text { Deviation } \\
\text { from Mean }\end{array}$ \\
\hline $\mathrm{B}$ & Center & A \& B & 2 & GT-49 & 45.0 & 45.0 & 1.7 & 4.4 \\
\hline B & Center & $A \& B$ & 3 & GT -48 & 45.0 & 45.0 & 1.3 & 2.6 \\
\hline A & Center & A & 2 & GT-38 & 90.0 & 70.0 & 1.3 & 2.6 \\
\hline A & Center & A & 3 & GT -37 & 90.0 & 70.0 & 2.3 & 5.3 \\
\hline A & Center & $A \& B$ & 2 & GT-27 & 90.0 & 70.0 & 7.2 & 13.8 \\
\hline A & Center & A \& B & 3 & GT-34 & 90.0 & 70.0 & 3.2 & 7.9 \\
\hline B & Center & B & 2 & GT-46 & 90.0 & 70.0 & 1.1 & 1.9 \\
\hline B & Center & B & 3 & GT -47 & 90.0 & 70.0 & 1.7 & 2.9 \\
\hline B & Center & $A \& B$ & 2 & GT-52 & 90.0 & 70.0 & 6.3 & 12.3 \\
\hline B & Center & $A \& B$ & 3 & GT-54 & 90.0 & 70.0 & 3.9 & 9.1 \\
\hline A & Far Left & A \& B & 2 & GT-28 & 90.0 & 70.0 & 5.2 & 9.8 \\
\hline A & Far Left & A \& B & 2 & GT-31 & 90.0 & 70.0 & 4.5 & 13.1 \\
\hline A & Far Left & A \& B & 3 & GT-32 & 90.0 & 70.0 & 3.2 & 6.6 \\
\hline A & Far Right & A \& B & 2 & GT-29 & 90.0 & 70.0 & 10.0 & 28.3 \\
\hline A & Far Right & $A \& B$ & 3 & GT-33 & 90.0 & 70.0 & 2.8 & 5.8 \\
\hline A & Near Left & $A \& B$ & 2 & GT-51 & 90.0 & 70.0 & 2.0 & 4.5 \\
\hline A & Near Left & $A \& B$ & 3 & GT-36 & 90.0 & 70.0 & 2.9 & 5.5 \\
\hline A & Near Right & $A \& B$ & 2 & GT-30 & 90.0 & 70.0 & 5.7 & 9.6 \\
\hline A & Near Right & $A \& B$ & 3 & GT-35 & 90.0 & 70.0 & 3.5 & 7.9 \\
\hline
\end{tabular}


Table B.2 lists the particle tracer uniformity results for the model stack. Only the data for Test Ports 2 and 3 are shown. The model Test Port 3 was just 1.5 DIA closer to the nearest upstream disturbance than the test ports on the 3410 Building Filtered Exhaust Stack. The last column shows the uniformity results for the combination of operating parameters tested.

Table B.2. Particle-Tracer Uniformity Tests with Dampers

\begin{tabular}{ccccccc}
\hline $\begin{array}{c}\text { Injection } \\
\text { Port }\end{array}$ & $\begin{array}{c}\text { Operating } \\
\text { Fans }\end{array}$ & $\begin{array}{c}\text { Test } \\
\text { Port }\end{array}$ & Run No. & $\begin{array}{c}\text { Control } \\
\text { Damper Setting } \\
\text { (degrees) }\end{array}$ & $\begin{array}{c}\text { Back Flow } \\
\text { Damper Setting } \\
\text { (degrees) }\end{array}$ & $\begin{array}{c}\text { Normalized } \\
\% \text { COV }\end{array}$ \\
\hline A & A \& B & 2 & PT-12 & 90 & 70 & 13.75 \\
A & A \& B & 2 & PT-21 & 90 & 70 & 7.41 \\
A & A \& B & 3 & PT-13 & 90 & 70 & 9.72 \\
A & A \& B & 3 & PT-20 & 90 & 70 & 8.12 \\
A & A & 2 & PT-15 & 90 & 70 & 2.46 \\
A & A & 3 & PT-14 & 90 & 70 & 3.73 \\
B & B & 2 & PT-18 & 90 & 70 & 3.02 \\
B & B & 3 & PT-19 & 90 & 70 & 3.61 \\
\hline
\end{tabular}


PNNL-19562

RPT-STMON-005

\title{
Distribution
}

\begin{abstract}
No. of
\end{abstract}
Copies

\section{ONSITE}

$9 \quad$ Pacific Northwest National Laboratory

JA Glissmeyer (3) K3-54

JM Barnett (2) J2-25

JE Flaherty K9-30

JT Hickman J2-09

RJ Steele J2-53

RS Sallee J2-19

Dist. 1 


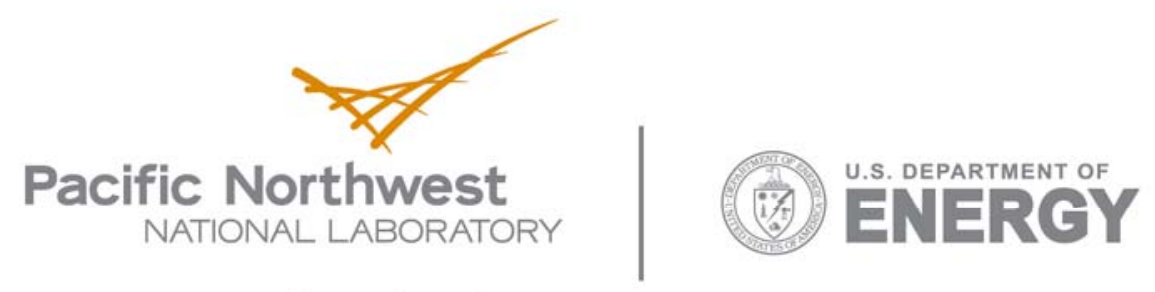

902 Battelle Boulevard

P.O. Box 999

Richland, WA 99352

1-888-375-PNNL (7665)

www.pnl.gov 